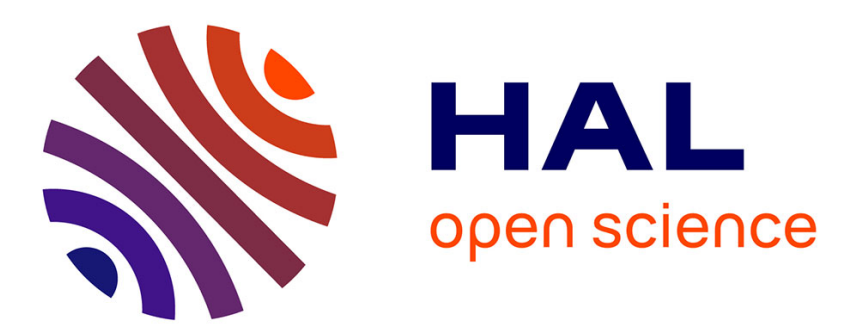

\title{
Regulation Of Prostate Cancer Cell Proliferation By Somatostatin Receptor Activation
}

\author{
Massimiliano Ruscica, Marica Arvigo, Federico Gatto, Elena Dozio, Daniel \\ Feltrin, Michael D. Culler, Francesco Minuto, Marcella Motta, Diego Ferone, \\ Paolo Magni
}

\section{To cite this version:}

Massimiliano Ruscica, Marica Arvigo, Federico Gatto, Elena Dozio, Daniel Feltrin, et al.. Regulation Of Prostate Cancer Cell Proliferation By Somatostatin Receptor Activation. Molecular and Cellular Endocrinology, 2009, 315 (1-2), pp.254. 10.1016/j.mce.2009.11.006 . hal-00547664

\section{HAL Id: hal-00547664 https://hal.science/hal-00547664}

Submitted on 17 Dec 2010

HAL is a multi-disciplinary open access archive for the deposit and dissemination of scientific research documents, whether they are published or not. The documents may come from teaching and research institutions in France or abroad, or from public or private research centers.
L'archive ouverte pluridisciplinaire HAL, est destinée au dépôt et à la diffusion de documents scientifiques de niveau recherche, publiés ou non, émanant des établissements d'enseignement et de recherche français ou étrangers, des laboratoires publics ou privés. 


\section{Accepted Manuscript}

Title: Regulation Of Prostate Cancer Cell Proliferation By Somatostatin Receptor Activation

Authors: Massimiliano Ruscica, Marica Arvigo, Federico Gatto, Elena Dozio, Daniel Feltrin, Michael D. Culler, Francesco Minuto, Marcella Motta, Diego Ferone, Paolo

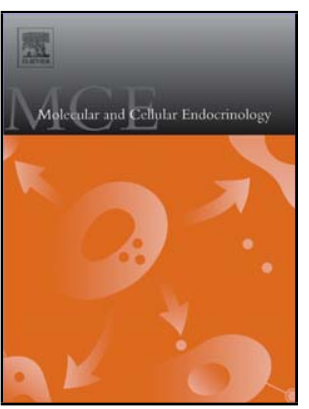

Magni

PII:

DOI:

Reference:

S0303-7207(09)00571-1

doi:10.1016/j.mce.2009.11.006

MCE 7370

To appear in:

Molecular and Cellular Endocrinology

Received date:

16-7-2009

Revised date:

5-11-2009

Accepted date:

15-11-2009

Please cite this article as: Ruscica, M., Arvigo, M., Gatto, F., Dozio, E., Feltrin, D., Culler, M.D., Minuto, F., Motta, M., Ferone, D., Magni, P., Regulation Of Prostate Cancer Cell Proliferation By Somatostatin Receptor Activation, Molecular and Cellular Endocrinology (2008), doi:10.1016/j.mce.2009.11.006

This is a PDF file of an unedited manuscript that has been accepted for publication. As a service to our customers we are providing this early version of the manuscript. The manuscript will undergo copyediting, typesetting, and review of the resulting proof before it is published in its final form. Please note that during the production process errors may be discovered which could affect the content, and all legal disclaimers that apply to the journal pertain. 


\section{REgUlation OF PROSTATE CANCER CELL PROLIFERATION BY SOMATOSTATIN RECEPTOR ACTIVATION}

ABBREVIATED TITLE: SRIF receptor activation in prostate cancer

Ruscica Massimiliano ${ }^{1 *}$, Arvigo Marica ${ }^{2 *}$, Gatto Federico ${ }^{2}$, Dozio Elena ${ }^{3}$, Feltrin Daniel ${ }^{1}$, Culler Michael D. ${ }^{4}$, Minuto Francesco ${ }^{2}$, Motta Marcella ${ }^{1}$, Ferone Diego ${ }^{2}$, and Magni Paolo ${ }^{1}$

"These authors equally contributed

10

11

${ }^{1}$ Department of Endocrinology, Pathophysiology and Applied Biology, and ${ }^{3}$ Department of Human Morphology and Biomedical Sciences "Citta' Studi", Università degli Studi di Milano, Italy; ${ }^{2}$ Department of Endocrinological \& Medical Sciences and Center of 14 Excellence for Biomedical Research, Università degli Studi di Genova, Italy; ${ }^{4}$ Biomeasure 15 Incorporated / IPSEN, Milford, Massachusetts, USA

16

ADDRESS CORRESPONDENCE TO: Paolo Magni, MD PhD; Department of Endocrinology, Pathophysiology and Applied Biology; via G. Balzaretti, 9; 20133 Milano Italy; tel. ++39-02-503.18229, fax ++39-02-503.18204; e-mail paolo.magni@unimi.it

KEY WORDS: androgen-dependent prostate cancer, somatostatin analogs, cell proliferation, somatostatin receptor subtypes dimerization, IGFs system

DISCLOSURE STATEMENT: The authors have nothing to disclose. 


\section{ABSTRACT}

Although some evidence supports the antitumoral effects of somatostatin (SRIF) and related agonists, the available data in prostate cancer $(\mathrm{PCa})$ model systems and clinical studies are few, conflicting and not conclusive. This study investigated the effects of lanreotide and new mono- and bi-specific SRIF agonists on proliferation, ligand-driven SRIF receptor (sst) dimerization and secretory pattern of the IGF system in LNCaP cells, a model of androgendependent PCa. $\mathrm{LNCaP}$ expressed all sst ${ }_{s}$, but sst ${ }_{4}$. Among them, sst $_{1}$ and sst $_{3}$ were inversely regulated by serum concentration. $\mathrm{Sst}_{1} / \mathrm{sst}_{2}$ and $\mathrm{sst}_{2} / \mathrm{sst}_{5}$ dimers were constitutively present and further stabilized by treatment with BIM-23704 ( $\left.\mathrm{sst}_{1} / \mathrm{sst}_{2}\right)$ and BIM-23244 (sst $\left.2 / \mathrm{sst}_{5}\right)$, respectively. Dose-response studies showed that lanreotide and BIM-23244 were significantly more potent in inhibiting LNCaP cell proliferation than BIM-23120 (sst $\left.{ }_{2}\right)$ and BIM-23206 (sst $t_{5}$ ) alone or in combination. Treatment with BIM-23296 (sst ${ }_{1}$ ) markedly reduced cell proliferation, whereas exposure to BIM-23704 resulted in a lower cell growth inhibition. The antiproliferative effects of BIM-23244, lanreotide and BIM-23704 were unchanged, reduced and abolished by the sst $_{2}$ antagonist BIM-23627, respectively. All SRIF analogs caused a significant induction in p2 $7^{\mathrm{Kipl}}$ and $\mathrm{p} 21$ and down-regulation of protein expression of cyclin E, as well as reduced IGF-I and IGF-II secretion. In particular, the administration of exogenous IGF-I, at variance to IGF-II, counteracted the inhibitory effect on cell proliferation of these compounds. Moreover, SRIF agonists reduced endogenous IGFBP-3 proteolysis. These results show that, in $\mathrm{LNCaP}$ cells, activation of $\mathrm{sst}_{1}$ and $\mathrm{sst}_{2} / \mathrm{sst}_{5}$ results in relevant antiproliferative/antisecretive actions.

\section{INTRODUCTION}

Somatostatin (SRIF) is an inhibitory tetradecapeptide hormone with exocrine, endocrine, paracrine, and autocrine activities, which plays an important regulatory role in several cell functions, including inhibition of endocrine secretion and cell proliferation (Hejna et al., 2002; Tejeda et al., 2006). Most of the effects of SRIF and of its currently available analogs are mediated via five different $\mathrm{G}$ protein-coupled receptor (GPCRs), codenamed sst ${ }_{1-5}$ (Patel 1999). Sst $_{\mathrm{s}}$ are expressed in a tissue- and subtype-selective manner in both normal and neoplastic cells, and the majority of SRIF target tissues express multiple sst ${ }_{\mathrm{s}}$ (Reubi et al., 2001). Recent data suggest that when $\mathrm{sst}_{\mathrm{s}}$ are coexpressed may interact forming homo- and hetero-dimers also with other GPCRs, altering their original pharmacological and functional profiles (Krantic et al., 2004).

Prostate cancer ( $\mathrm{PCa}$ ) is the most frequently diagnosed malignant neoplasm among men in the Western world and remains the second leading cause of cancer-related deaths, with an incidence estimated at $12 \%$ in the European Union and at 29\% in the USA (Djavan 2007). In addition to the traditional anti-androgen hormonal therapy, commonly used in androgendependent PCa, some evidence suggest SRIF receptors as a target for imaging and treatment of PCa cancer with SRIF analogs (Kalkner et al., 1998; Nilsson et al., 1995; Thakur et al., 1997). Indeed, sst ${ }_{s}$ have been identified in the smooth muscle nodules of both normal and hyperplastic prostatic tissues (Reubi et al., 1995), in human PCa peritumoral veins (Reubi 2003) and in specimens of primary human PCa with Gleason score ranging from 6 to 10 (Halmos et al., 2000).

Few data exist about the selected antiproliferative effect of SRIF and related agonists on PCa model systems. In particular, SRIF was shown to reduce the proliferation of LNCaP cells (Brevini et al., 1993) and adjuvant therapy with lanreotide ( $\mathrm{sst}_{2}$ and partial $\mathrm{sst}_{5}$ agonist) was found effective in slowing cancer growth in castrated Copenhagen rats bearing Dunning R3327-H prostate tumors (Bogden et al., 1990). Regarding clinical studies, the results obtained in trials conducted on advanced hormone-refractory prostate cancer patients using lanreotide are conflicting and not conclusive (Figg et al., 1995; Maulard et al., 1995) and thus the ideal 
SRIF analog still needs to be determined. Moreover, lanreotide and octreotide ( $\mathrm{sst}_{2} / \mathrm{sst}_{5}$ agonist) have been shown to potentiate the antitumoral effect of docetaxel in vitro (Erten et al., 2009; Lo Nigro et al., 2008). In addition, the SRIF analog vapreotide has been conjugated to doxorubicin and then used as a carrier molecule to inhibit PC-3 cell proliferation (Plonowski et al., 1999).

SRIF effect on tumors may be the result of direct antiproliferative action and indirect suppression of the secretion of growth-promoting hormones and growth factors, involved in the control of tumor cell growth. In particular, increased IGF-I serum levels seem associated with increased risk of PCa (Djavan et al., 2001; Russell et al., 1998); in some experimental models, progression to androgen independence has been linked to an increased expression of IGF-I and IGF-IR (Nickerson et al., 2001).

Among the different available in vitro PCa models, the epithelial LNCaP cells, a line established from supraclavicular lymph node metastases (Horoszewicz et al., 1980), represent a useful experimental tool, since they maintain several characteristics of human $\mathrm{PCa}$, such as the dependence on androgen, the presence of androgen receptors, and the capability to produce a series of androgen-regulated prostate-secreted proteins, such as prostatic specific antigen (PSA) and acid phosphatase (Horoszewicz et al., 1983). The aim of the present study was to investigate the effects of the activation of sst $t_{\mathrm{s}}$ by using new monoand bi-specific SRIF agonists on: a) LNCaP cell proliferation, including the evaluation of proteins involved in the regulation of the cell cycle; b) sst ${ }_{\mathrm{s}}$ dimerization; and c) the secretory pattern of IGF-I/-II.

\section{Materials and methods}

Cell Cultures. LNCaP and Calu-6, a human non-small cell lung cancer cells (NSCLS), used as a positive control for sst protein expression, both from American Type Culture Collection (Rockville, MD), were grown at $37^{\circ} \mathrm{C}$ in a humidified $\mathrm{CO}_{2}$ incubator in monolayer. The culture medium for LNCaP was RPMI 1640, with $10 \mathrm{mg} / \mathrm{L}$ phenol red (Biochrom, Berlin, Germany), and 10\% FBS (Gibco, Grand Island, NY); for Calu-6 cells, the medium was MEM supplemented with $10 \%$ FBS, $1 \%$ non essential amino acids, $20 \mathrm{mg} / \mathrm{dL}$ gentamycin, $200 \mathrm{mM}$ glutamine, and $1 \mathrm{mM}$ sodium pyruvate. Subconfluent cells were harvested with $0.05 \%$ trypsin $/ 0.02 \%$ EDTA (Biochrom, Berlin, Germany) and were seeded in Petri dishes (Becton-Dickinson, Plymouth, UK) or in 96 well-plates (Viewplate-96; Perkin Elmer, Milan, Italy) depending on the experiments. Notably, according to our previous studies (Ruscica et al., 2006), the experimental protocol for proliferation studies included a switch of FBS concentration from $10 \%$ to $2 \%$, which allowed to maintain the cultures in good conditions.

RNA Extraction and RT-PCR analysis. For RNA studies, cells were washed with cold PBS, collected, snap-frozen in liquid nitrogen, and stored at $-80^{\circ} \mathrm{C}$ until RNA extraction. Nonfunctional pituitary adenoma (NFPA) and benign prostatic hyperplasia, obtained from surgery, were taken as positive controls (for $\mathrm{sst}_{1}, \mathrm{sst}_{2 \mathrm{~A}}, \mathrm{sst}_{3}, \mathrm{sst}_{5}$ ) and for $\mathrm{sst}_{4}$, respectively). Total cellular RNA was extracted with the phenol-chloroform method using the Tri Reagent solution (Sigma-Aldrich, Milan, Italy). RT-PCR analysis of the expression of the genes coding for SRIF and sst ${ }_{\mathrm{s}}$ was performed on total RNA samples, quantified after an initial DNAase digestion step using the Deoxyribonuclease I kit (Sigma-Aldrich, Milan, Italy). The RT reaction was carried out in a $20 \mathrm{ml}$ volume, using a commercially available kit (Superscript VILO ${ }^{\circledR}$ cDNA Synthesis Kit; Invitrogen, Milan, Italy). Negative control reactions omitting reverse transcriptase were carried out in parallel, confirming that no sample contamination by genomic DNA occurred (not shown). The primers used to detect the expression of the genes coding for human SRIF, human $\mathrm{sst}_{\mathrm{s}}\left(\mathrm{sst}_{1}, \mathrm{sst}_{2 \mathrm{~A}}, \mathrm{sst}_{3}, \mathrm{sst}_{4}\right.$ and $\mathrm{sst}_{5}$ ) and 18 s ribosomal protein were as follows: SRIF forward (5'- gAT gCT gTC CTg CCg CCT CCA g -3') and SRIF reverse (5'- ACA ggA TgT gAA AgT CTT CCA -3'); sst $_{1}$ forward (5'- ATg gTg gCC CTC AAg gCC gg -3') and sst $1_{1}$ reverse (5'- $\mathrm{CgC}$ ggT ggC gTA 
ATA gTC AA -3'); sst $_{2 \mathrm{~A}}$ forward (5'- gCC AAg ATg AAg ACC ATC AC -3') and sst $_{2 \mathrm{~A}}$ reverse (5'- gAT gAA CCC TgT gTA CCA AgC -3'); sst $_{3}$ forward (5'- CgT CAg Tgg CgT TCT gAT CC-3') and sst $_{3}$ reverse (5'- TgT gCC gCA ggA CCA CAT A - $\left.3^{\prime}\right)$; sst $_{4}$ forward (5'- CAT ggT CgC TAT CCA gTg CAT-3') and sst ${ }_{4}$ reverse (5'- gAA ggA TCA CgA AgA TgA CCA-3'); sst $_{5}$ forward (5'- CCg TCT TCA TCA TCT ACA Cgg -3') and sst ${ }_{5}$ reverse (5'- ggC CAg gTT gAC gAT gTT gA -3'); $18 \mathrm{~s}$ forward (5'- CTC gCT CCT CTC CTA CTT gg -3') and 18 s reverse (5'- CCA TCg AAA gTT gAT Agg gC -3'). Liquid controls and reactions without RT resulted in negative amplifications. The identity of the PCR products was confirmed by DNA sequencing (not shown).

RNA analysis of sst $t_{s}$ by real-time PCR. Since, as mentioned above, FBS supplementation of culture medium in cell proliferation studies switched from standard conditions (10\%) to $2 \%$, we assessed whether such variation affected $\mathrm{sst}_{\mathrm{s}}$ gene and protein expression. To this aim, real-time RT-PCR was carried out using an ABI PRISM 7000 sequence detection system (Applied Biosystems, Milan, Italy). The ribosomal protein L13a (RPL13A) was used as internal control: RPL13A forward (5' GCGGCTGCCGAAGATG 3'), RPL13A reverse (5' GGCCTCGACCATCAAGCA 3') and RPL13A probe (5' CAGGACCTGCACCTCC 3'). Each sample in triplicate underwent real-time PCR analysis for $\mathrm{sst}_{1}, \mathrm{sst}_{3}$ and RPL13A. All probes used (custom TaqMan MGB probes, Applied Biosystems, Milan, Italy) contained a reporter fluorescent dye 6-carboxy-fluorescein (FAM) at the 5' end, and a minor-groovebinder moiety and a non-fluorescent quencher dye at the 3' end. Briefly, the $25 \mu \mathrm{L}$ reaction mixture consisted of $12.5 \mu \mathrm{L} \mathrm{2x}$ TaqMan Master Mix (Applied Biosystems, Milan, Italy), $1.25 \mu \mathrm{L}$ of specific 20X gene expression Assay Mix, $1 \mu \mathrm{L}$ cDNA and $10.25 \mu \mathrm{L}$ nuclease-free water. Calculation of the relative expression levels of the target mRNAs was conducted based on the relative standard curve method (singleplex).

Immunoblotting. Membrane receptors were obtained from $\mathrm{LNCaP}$ and Calu- 6 cells by solubilization in lysis buffer (20 mM HEPES, $5 \mathrm{mM}$ EDTA, $3 \mathrm{mM}$ EGTA, $150 \mathrm{mM} \mathrm{NaCl}, 1$ $\mathrm{mM}$ PMSF, $10 \mu \mathrm{g} / \mathrm{mL}$ soybean trypsin inhibitor, $10 \mu \mathrm{g} / \mathrm{mL}$ leupeptin, $50 \mu \mathrm{g} / \mathrm{mL}$ bacitracin). and subsequent centrifugation at 20,000 x g. Membrane pellet was resuspended with lysis buffer additioned with $4 \mathrm{mg} / \mathrm{mL}$ dodecyl-D-maltoside, incubated $1 \mathrm{~h}$ on ice and centrifugated at $20.000 \mathrm{x} \mathrm{g}$ at $4^{\circ} \mathrm{C}$. Glycosylated proteins were immobilized by recycling the solubilized membrane proteins of the supernatant through a $0.5-\mathrm{mL}$ wheat-germ agglutinin (Vector Laboratories, Burlingame, CA) column overnight at $4^{\circ} \mathrm{C}$. The column was eluted with lysis buffer containing $3 \mathrm{mM} \mathrm{N}, \mathrm{N}$ ', N-triacetylchitotriose (Sigma-Aldrich, St. Louis, MO). The protein content of the eluted protein was assessed by Bradford assay. Glycosylated proteins $(10 \mu \mathrm{g})$ was denatured and fractionated on $12.5 \%$ SDS-PAGE and then transferred electrophoretically to Hybond C-extra nitrocellulose membranes. After transfer, nonspecific binding sites were blocked by treating membranes with Tris-buffered saline-Tween (TBS-T) containing 5\% nonfat dried milk for $1 \mathrm{~h}$ at $22^{\circ} \mathrm{C}$. To evaluate the presence of SRIF receptors, after five washes with TBS-T, membranes were incubated for $16 \mathrm{~h}$ at $4^{\circ} \mathrm{C}$ with a 1:500 dilution of $\mathrm{sst}_{1}, \mathrm{sst}_{2 \mathrm{~A}}, \mathrm{sst}_{3}, \mathrm{sst}_{4}$ and sst ${ }_{5}$ (Santa Cruz Biotechnology, CA) polyclonal antibodies and incubated for $1 \mathrm{~h}$ at $22^{\circ} \mathrm{C}$ with 1:2,000 dilution of horseradish peroxidase-linked antirabbit IgG. To evaluate the cell cycle arrest, membranes were then incubated with a diluted solution of the primary antibody (anti-p21, 1:100; anti-p27 $7^{\text {Kipl }}$, 1:100; anti-cycline E, 1:100 (Cell Signaling Technology, MA); anti-tubulin, 1:2,000 (Sigma-Aldrich, St. Louis, MO) and the subsequent incubation with a secondary antibody $(1: 8,000 ; 1: 5,000 ; 1: 5,000$ and 1:8,000, respectively) conjugated with peroxidase was performed at room temperature for $2 \mathrm{~h}$. Membranes were washed with TBS-T, as before, immersed in the chemiluminescence detection solution and exposed to radiographic film.

Immunoprecipitation (IP). Membrane protein preparations $(300 \mu \mathrm{g})$ were subjected to immunoprecipitation with anti-sst ${ }_{2}$ and - sst $_{5}$ polyclonal antibody (Santa Cruz Biotechnology, 
$\mathrm{CA}$ ) in the presence of $20 \mu \mathrm{L}$ of protein A-Agarose (Santa Cruz Biotechnology, CA). After washing steps with lysis buffer, the Protein-A conjugated immunocomplex was boiled for 5 min with sample buffer (6\% SDS, $0.24 \mathrm{M}$ Tris- $\mathrm{HCl} 0.5 \mathrm{M} \mathrm{pH} 6.8,30 \%$ Glycerol, $0.3 \mathrm{mg} / \mathrm{ml}$ bromophenol blue, $50 \mathrm{mM}$ DTT) to denature and separate the immunocomplex from protein A-Agarose. After a centrifugation at $1000 \mathrm{xg}$ for $30 \mathrm{sec}$, the supernatants were processed as previously described in the "immunoblotting" section.

Sst $t_{5}$-selective agonists. The SRIF analogs: lanreotide, bi-specific sst $2 /$ sst $_{5}$-preferential compound BIM-23244 (Gordon et al., 2003), sst 2 -preferential compound BIM-23120 (degli Uberti et al., 2002), sst5-preferential compound BIM-23206 (Coy et al., 1990), bi-specific sst $_{1} /$ sst $_{2}$-preferential compound BIM-23704, sst $_{1}$-preferential compound BIM-23296 and sst $_{2}$ antagonist BIM-23627 used in this study and their respective affinities $\left(\mathrm{IC}_{50}\right)$ to the different sst $_{\mathrm{s}}$ are listed in Table 1 . All experimental compounds were kindly provided by Biomeasure (Milford, MA), while SRIF-14 (SRIF) was purchased from Sigma-Aldrich (Milan, Italy).

Cell proliferation studies. To estimate the effect of SRIF analogs alone or in combination with exogenous IGF-I and -II on cell proliferation, $15^{*} 10^{3} \mathrm{LNCaP}$ cells were seeded in a 96well plates in a final volume of $200 \mu \mathrm{L}$ per well and incubated at $37^{\circ} \mathrm{C}$ in a humidified $5 \%$ $\mathrm{CO}_{2}$ atmosphere for $48 \mathrm{~h}$. The culture medium was replaced by adding $180 \mu \mathrm{L}$ of experimental medium (RPMI 1640/2\% FBS) containing human SRIF and SRIF analogs (range: $10^{-7}-10^{-11} \mathrm{M}$ ), when used alone or at the concentration of $10^{-9} \mathrm{M}$, when used in combination with IGF-I and IGF-II (both at $7 \mathrm{nM}$ ). Thus, the incubation was carried on for further $48 \mathrm{~h}$. Treatments were renewed every $24 \mathrm{~h}$. Twenty microliter of $100 \mu \mathrm{M}$ 5'-bromo2'deoxyuridine (BrdU labeling solution, Delfia cell proliferation kit, Perkin Elmer, Milan, Italy) were added to the cultures $24 \mathrm{~h}$ before the end of the incubation. Cells were subsequently fixed (fix solution, $100 \mu \mathrm{L}$ per well) for $30 \mathrm{~min}$ and then incubated, at room temperature, for further $120 \mathrm{~min}$ with a primary monoclonal antibody against $\mathrm{BrdU}(0.5$ $\mu \mathrm{g} / \mathrm{mL}$ ) conjugated with Europium (Eu; Anti-BrdU-Eu working solution). Finally, after adding a specific inducer solution $(200 \mu \mathrm{L} / \mathrm{well})$, the Eu-fluorescence was measured in a time-resolved fluorometer. To exclude any unspecific binding of both BrdU and anti-BrdU$\mathrm{Eu}$, for every experiment a row without cells (only medium) has been analyzed. Results (Eucounts) were obtained by determining the mean value of at least 4 experiments in 8 replicates.

Conditioned medium. To prepare conditioned media (CM), LNCaP cells were plated in 100$\mathrm{mm}$ Petri dishes (Becton-Dickinson, Plymouth, UK) and grown in RPMI (Biochrom, Berlin, Germany) with $10 \% \mathrm{FBS}$, at $37^{\circ} \mathrm{C}$ in a humidified $\mathrm{CO}_{2}$ incubator in monolayer, until they reached $60-70 \%$ confluence. Thus, cells were washed twice with PBS with $\mathrm{Ca}^{++} / \mathrm{Mg}^{++}$, and cultured for $36 \mathrm{~h}$ in RPMI supplemented with $0.1 \%$ BSA (Sigma-Aldrich, Milan, Italy) in the presence or absence of SRIF and SRIF analogs at the concentration of $10^{-9} \mathrm{M}$ (which represents the dose to which all SRIF analogs show an bi-specific sst $1 /$ sst $_{2}$-preferential compound effect) and that of $\mathrm{sst}_{2}$ antagonist at the concentration of $10^{-7} \mathrm{M}$ (Zatelli et al., 2001). Treatments with all compounds did not modify the survival rate of the cells (viable cells $>95 \%$ according to trypan blue exclusion) or induce any morphological change (data not shown). The supernatants were collected, centrifuged at $1,000 \mathrm{xg}$ and stored at $-80^{\circ} \mathrm{C}$ until testing.

Chromatographic profile of the secreted IGF-I and IGF-II. CM was acidified by $18 \mathrm{~h}$ dialysis at $4^{\circ} \mathrm{C}$ against $1 \mathrm{M}$ acetic acid in Spectra-Por 6 membranes (molecular weight (mw) cut off, $1000 \mathrm{Da})$, lyophilized and resuspended with $0.1 \mathrm{M}$ acetic acid- $0.15 \mathrm{M} \mathrm{NaCl}(\mathrm{pH}$ of the mixture <3). Then, IGF-I and IGF-II were separated from IGFBPs by gel filtration on FPLC Superdex-75 column equilibrated with $0.1 \mathrm{M}$ acetic acid-0.15 M NaCl, pH 2.75. Fractions were pooled at $0.1 \mathrm{Kav}$ intervals, lyophilized, reconstituted in $1 \mathrm{~mL}$ PBS and analyzed for 
IGF-I and for IGF-II. IGF-I and IGF-II contents of media were evaluated in the fractions eluted from the Superdex-75 column in the mw range of the free peptide.

Measurement of IGF-I and IGF-II in the conditioned medium. IGF-I was measured by using a commercially available radioimmunoassay (RIA) kit (Biosource; Nivelles, Belgium). The sensitivity of the RIA assay was $0.02 \mathrm{ng} / \mathrm{mL}$; the intra-assay and inter-assay coefficients of variation were $6.0 \%$ and $7.5 \%$, respectively. IGF-II was measured by an immunoradiometric assay (IRMA) (Diagnostic Systems Laboratories, Texas). The sensitivity of the IRMA assay was $0.13 \mathrm{ng} / \mathrm{mL}$; the intra-assay and inter-assay coefficients of variation were $5.3 \%$ and $8.7 \%$, respectively. IGF-I and -II concentrations in the conditioned media were normalized to the protein content.

rh-IGFBP-3 proteolysis. To evaluate the effect of SRIF analog treatment on the protease activity of CM on rh-IGFBP-3, aliquots of CM corresponding to $5 * 10^{5}$ cells were lyophilized, reconstituted with $100 \mu \mathrm{L}$ of distilled $\mathrm{H}_{2} \mathrm{O}$ and incubated with $50 \mathrm{ng}$ of deglycosylated rh-IGFBP-3 in the presence of $2 \mathrm{mM} \mathrm{CaCl}_{2}$ at $37^{\circ} \mathrm{C}$ for $5 \mathrm{~h}$. The amount of residual intact rh-IGFBP-3 was visualized by immunoblotting, by using a 1:5000 dilution of anti-IGFBP-3 antiserum leading to the identification of a single band of $30 \mathrm{kDa}$ (Tressel et al., 1991). Deglycosylated rh-IGFBP-3 and anti-IGFBP-3 antiserum were provided by Dr. A. Sommer (INSMED Inc., Richmond, VA).

Analysis of the data. Statistical analysis was performed using the Prism statistical analysis package (GraphPad Software, San Diego, CA). Data are given as Mean \pm SD of three independent experiments. Differences between treatment groups were evaluated by one way ANOVA and were considered significant at $\mathrm{P} \leq 0.05$.

\section{RESULTS}

Sst $t_{s}$ gene and protein expression. Before any test with SRIF agonists, we sought to determine the gene and protein expression pattern of sst $_{1-5}$ in LNCaP cells, by means of RT-PCR and Western blot analysis. By using specific oligoprimers, we detected specific products of 318 bp for $\mathrm{sst}_{1}, 414 \mathrm{bp}$ for $\mathrm{sst}_{2 \mathrm{~A}}, 95 \mathrm{bp}$ for $\mathrm{sst}_{3}$ and $226 \mathrm{bp}$ for $\mathrm{sst}_{5}$. Ribosomal $18 \mathrm{~s}$ was used as internal control for RT-PCR (250 bp) (Fig. 1A). Moreover, the analysis of LNCaP cell extracts by immunobloting using, specific human $\mathrm{sst}_{\mathrm{s}}$ antibodies, showed immunoreactive bands of apparent mw of $65 \mathrm{kDa}\left(\mathrm{sst}_{1}\right), 45-90 \mathrm{kDa}\left(\mathrm{sst}_{2 \mathrm{~A}}\right), 45-70 \mathrm{kDa}\left(\mathrm{sst}_{3}\right), 40-70 \mathrm{kDa}\left(\mathrm{sst}_{5}\right.$ ), depending on protein glycosylation (Fig. 1B). Neither gene nor protein expression of sst $_{4}$ was detected (Fig, 1A, B).

Experimental conditions modulate sst $_{1}$ and sst $_{3}$ gene and protein expression. The experimental conditions for LNCaP cell proliferation studies include a switch of FBS supplement from $10 \%$ (regular culture conditions) to $2 \%$, according to our previous experience (Ruscica et al. 2006). The presence of $2 \%$ FBS was associated with up-regulation of sst $_{1}$ and $\mathrm{sst}_{3}$ expression, while no changes were observed for $\mathrm{sst}_{2 \mathrm{~A}}$ and $\mathrm{sst}_{5}$ (not shown). In particular, real-time RT-PCR analysis showed that sst $_{1}$ mRNA and sst $_{3}$ mRNA expression were up-regulated (mean increment at $48 \mathrm{~h}, \sim 2.4$-fold and $\sim 2.9$-fold, respectively) (Fig. $2 \mathrm{~A}$ ). Similarly, protein expression of the $s t_{1}$ and sst $_{3}$ were increased (for both $\sim+200 \%$ ) (Fig. 2B).

Cell proliferation studies. LNCaP cells were subjected to a 48-h dose-response study (10${ }^{11} / 10^{-7} \mathrm{M}$ ) with SRIF and different SRIF agonists. All these agents were found to inhibit cell proliferation to some extent with a peculiar profile related to the sst specificity of each compound. The native ligand, SRIF, was significantly effective in inhibiting cell growth, over the whole dose range tested, $\left(-43 /-57 \%\right.$; P 0.01) (Fig. 3A). The bi-specific sst $2_{2} /$ sst $_{5-}$ preferential agonist BIM-23244 was able to reduce LNCaP cell growth by $30 \%$ at $10^{-11} \mathrm{M}$, 
then reaching a plateau of $-40 \%$ at $10^{-10}-10^{-7} \mathrm{M}(\mathrm{p}<0.01)$. Lanreotide resulted very effective at the lower concentrations $\left(-49 /-46 \%\right.$ at $\left.10^{-11}-10^{-10} \mathrm{M}\right)$, with a lesser but still significant activity at $10^{-9}-10^{-7} \mathrm{M}(-27 /-23 \%)$ (Fig. 3A). The mono-specific $\mathrm{sst}_{2}$ preferential compound BIM-23120 showed a maximal cell growth inhibition at $10^{-11} \mathrm{M}(-21 \%, \mathrm{p}<0.01)$, and progressively showed a lower efficacy with increasing doses (Fig. 3B). The mono-specific sst $_{5}$ preferential compound BIM-23206 showed a statistically significant inhibitory effect only at $10^{-11} \mathrm{M}(-15 \%, \mathrm{p}<0.01)$ (Fig. 3B). To evaluate the possible effect played by the simultaneous activation of $\mathrm{sst}_{2}$ and $\mathrm{sst}_{5}$ receptors, we treated LNCaP cells with BIM-23120 $\left(\mathrm{sst}_{2}\right)$ and BIM-23206 ( $\left.\mathrm{sst}_{5}\right)$ in combination. Interestingly, this treatment resulted in an additive effect, compared to each compound alone, over the $10^{-11}-10^{-8} \mathrm{M}$ range, however reaching a lesser inhibition $(-19 /-27, \mathrm{P}<0.01)$ compared to BIM-23244 ( $\left.\mathrm{sst}_{2} / \mathrm{sst}_{5}\right)$ and lanreotide (Fig. 3B). Treatment with the sst $_{1}$-preferential agonist BIM-23296 markedly reduced cell proliferation $\left(-28 /-36 \%\right.$ at $\left.10^{-11}-10^{-7} \mathrm{M} ; \mathrm{P}<0.01\right)$, whereas exposure to the bispecific sst $_{1} /$ sst $_{2}$-preferential agonist BIM-23704 resulted in a significant, but lower cell growth inhibition over the whole range of doses $\left(-23 /-13 \%\right.$ at $\left.10^{-11}-10^{-7} \mathrm{M} ; \mathrm{P}<0.01\right)$, with maximal efficacy at $10^{-8} \mathrm{M}$ (Fig. 3C). In order to clarify the importance of $\mathrm{sst}_{2}$ recruitment in the induction of the antiproliferative activity of the bi-specific compounds, BIM-23704 $\left(\mathrm{sst}_{1} / \mathrm{sst}_{2}\right), \mathrm{BIM}-23244\left(\mathrm{sst}_{2} / \mathrm{sst}_{5}\right)$ and lanreotide, cells were treated with the selective $\mathrm{sst}_{2}$ antagonist BIM-23627 $\left(10^{-7} \mathrm{M}\right)$, alone or in combination with these agonists. BIM-23627 alone did not alter LNCaP cell growth compared with untreated control cells (Fig. 3D). In the presence of the antagonist, the effect of lanreotide was dramatically reduced from $-49 /-23 \%$ to $-11 /-4 \%$ (at $10^{-11}-10^{-7} \mathrm{M}$ ) (Fig 3D), whereas the effect of BIM-23244 was not modified (data not shown). Moreover, the inhibition of BrdU incorporation induced by BIM-23704 was totally abolished, in the presence of the antagonist, over the $10^{-11}-10^{-8} \mathrm{M}$ dose range (Fig $3 \mathrm{E})$. The above-reported effects on cell proliferation with $\mathrm{BrdU}$ were paralleled and confirmed by the $\left[{ }^{3} \mathrm{H}\right]$ thymidine incorporation assay (data not shown). Thus, $\mathrm{sst}_{1-}$ and $\mathrm{sst}_{2} / \mathrm{sst}_{5}$-preferential SRIF agonists were found to be the most effective inhibitors of LNCaP growth.

$S s t_{1} / s s t_{2}$ and $s s t_{2} / s s t_{5}$ dimerization study. To assess whether treatment with bi-specific SRIF analogs may modulate sst heterodimerization, IP/WB experiments were performed. A small amount of $\mathrm{sst}_{1} / \mathrm{sst}_{2}$ and $\mathrm{sst}_{2} / \mathrm{sst}_{5}$ heterodimers was constitutively present on LNCaP cell membranes (Fig. 4A/B). Treatment with BIM-23704 ( sst $\left._{1} / \mathrm{sst}_{2}\right)$ increased the amount of sst $_{1}$ co-immunoprecipitated with $\mathrm{sst}_{2}$, which may probably reflect a stabilization of the $\mathrm{sst}_{1} / \mathrm{sst}_{2}$ heterodimers (Fig. 4A). Treatment with lanreotide increased the amount of the $\mathrm{sst}_{2}$ receptor co-immunoprecipitated with the $\mathrm{sst}_{5}$, also probably reflecting the stabilization of $\mathrm{sst}_{2} / \mathrm{sst}_{5}$ heterodimers. Treatment with the $\mathrm{sst}_{2} / \mathrm{sst}_{5}$-preferential compound BIM-23244 resulted in an even more pronounced effect compared to lanreotide (Fig. 4B). Compared with the constitutive levels, BIM-23244 did not affect the amount of $\mathrm{sst}_{1} / \mathrm{sst}_{2}$ heterodimers (Fig. 4A) and BIM-23704 did not affect that of $\mathrm{sst}_{2} / \mathrm{sst}_{5}$ heterodimers (Fig. 4B). Thus, the bi-specific $\mathrm{sst}_{1} / \mathrm{sst}_{2}$ and $\mathrm{sst}_{2} / \mathrm{sst}_{5}$-preferential compounds enhanced the stabilization of the corresponding heterodimers.

Effect of SRIF analogs treatment on protein expression of p27 $7^{K i p I}, p 21$ and cyclin E in LNCaP cells. The effect of SRIF analogs on the expression of proteins involved in cell cycle arrest was then evaluated. Relative density data revealed that all SRIF analogs caused a significant induction in $\mathrm{p} 27^{\mathrm{KipI}}$ and $\mathrm{p} 21$ and down-regulation of protein expression of cyclin E, compared to cells treated with media alone (fig. 5). In particular, BIM-23244 ( $\left.\mathrm{sst}_{2} / \mathrm{sst}_{5}\right)$ caused 1.6- and 2.4-fold increases of the protein expression of $\mathrm{p} 27^{\mathrm{Kipl}}$ and $\mathrm{p} 21$, respectively. as well as a significant decrement $(-34 \%)$ in cyclin E level. BIM-23926 (sst $\left.{ }_{1}\right)$ was able to increase p27 $7^{\text {KipI }}$ and p21 (1.74 and 2.63 fold. respectively) and reduce $(-11 \%)$ cyclin E protein levels. 
known to contribute to $\mathrm{PCa}$ progression through systemic and paracrine/autocrine mechanisms. Specifically, LNCaP cells were shown to secrete small amounts of IGFs. Thus, we evaluated the ability of SRIF agonists to regulate IGF-I and -II secretion by these cells, after a 48-h treatment. BIM-23244 (sst $\left.2 / \mathrm{sst}_{5}\right)$ and lanreotide significantly inhibited IGF-I ($91 \%$ and $-36 \%$, respectively) and IGF-II (-59 and $-68 \%$, respectively) secretion. The inhibitory effects of BIM-23244 on both IGFs and lanreotide on IGF-I were abolished by cotreatment with the sst $_{2}$ antagonist BIM-23627. Conversely, treatment with BIM-23704 $\left(\mathrm{sst}_{1} / \mathrm{sst}_{2}\right)$ produced a $+33 \%$ increase of IGF-I and a $-43 \%$ decrease of IGF-II secretion (Table 2 ), which were dramatically reduced in the presence of BIM-23627. Among the monospecific ligands, BIM-23926 (sst $\left.{ }_{1}\right)$ markedly reduced IGF-I (-85\%) and IGF-II (-68\%) secretion, BIM-23120 ( sst $\left._{2}\right)$ significantly inhibited IGF-I (-79\%) and slightly stimulated $(+19 \%)$ IGF-II secretion, BIM-23206 (sst 5 ) inhibited both IGF-I (-49\%) and IGF-II (-86\%) secretion (Table 2). In conclusion, the secretion of IGFs by LNCaP cells appears to be markedly affected by almost all SRIF analogs tested.

Effect IGFs on SRIF agonists-induced inhibition of LNCaP cell proliferation. In order to study the role of IGFs on growth of PCa cells, we evaluated the effect of exogenous IGF-I and IGF-II, tested alone or in combination with SRIF agonists, on LNCaP cell proliferation. As shown in Table 3, a 48-h treatment with IGF-I alone significantly increased LNCaP cell proliferation $(+18 \%)$. Moreover, the inhibitory effects of lanreotide, BIM-23244, BIM-23120, BIM-23206 and BIM-23926 was fully counteracted by the addition of IGF-I. On the contrary, the administration of exogenous IGF-II did not change LNCaP cell proliferation, nor affected the antiproliferative action of each SRIF agonist.

SRIF agonists reduce the proteolytic activity of LNCaP conditioned media. Another IGF system component with relevance to the local control of PCa progression is IGFBP-3, which binds IGF-I and also undergoes to degradation by proteolysis, resulting in lower IGF-Ibinding. Thus, we evaluated the ability of $\mathrm{CM}$ from $\mathrm{LNCaP}$ cells to cleave exogenous rhIGFBP-3 by WB. After a 5-h incubation with CM from untreated LNCaP cells, intact rhIGFBP-3 was dramatically reduced, compared to vehicle (PBS). Such extensive proteolytic cleavage was partially reduced by treatment of LNCaP cells with SRIF analogs. Moreover, combined treatment with the antagonist BIM-23627 and the mono-specific or bi-specific sst ${ }_{\mathrm{s}}$ analogs abolished the antiproteolytic effect induced by SRIF analogs (Fig. 4C). SRIF analogs, therefore, seem able to interfere with the IGF system also by reducing the proteolytic degradation of IGFBP-3.

\section{DISCUSSION}

The present study reports the substantial evidence for an important role of the SRIF system in controlling PCa cell proliferation. Specifically, four ( $\mathrm{sst}_{1-2-3-5}$ ) out of five $\mathrm{sst}_{\mathrm{s}}$ receptors were found to be expressed in the $\mathrm{LNCaP}$ cell line, an in vitro model of human androgendependent PCa. Their activation by selective SRIF agonists resulted in a significant antiproliferative effect with a peculiar pattern according to receptor subtype, ligand affinity and, possibly, receptor dimerization. Moreover, such treatments were also able to modulate the profile of the IGF system, known to be involved in PCa progression (Russell et al., 1998).

The sst $_{\mathrm{s}}$ expression profile observed in $\mathrm{LNCaP}$ cells partially differs from that reported in other studies in the same cell line, which showed either the expression of all receptors (Liu et al., 2008) or of some of them (Dizeyi et al., 2002; Taylor et al., 1994; Zapata et al., 2002). Moreover, a great heterogeneity exists in the pattern of sst $\mathrm{s}_{\mathrm{s}}$ espression in other PCa cell lines and normal prostate and PCa tissue (Halmos et al., 2000; Sinisi et al., 1997). Interestingly, sst $_{1}$ and sst $_{3}$ were markedly up-regulated by different experimental conditions, an observation in line with previous evidence of sst $_{\mathrm{s}}$ modulation by hormones. Indeed, it has been recently shown that in PCa cells, treatment with 5-aza decitabine and trichostatin in 
combination increased sst $t_{5}$ mRNA content (Liu et al. 2008), similarly to the effects observed in other cell systems after treatment with glucocorticoids or with estrogens (Djordjijevic et al., 1998; Kimura et al., 2008; Viguerie et al., 1987; Visser-Wisselaar et al., 1996). It has been also documented that hormone therapies may be responsible for a change in sst expression in PCa (Reubi 2004). Thus, one may speculate that combined androgen blockade therapy in PCa patients might possibly up-regulate the expression of some sst $_{\mathrm{s}}$, thereby improving some diagnostic applications (i.e., in vivo scintigraphy by using radiolabelledSRIF analogs) (Khan et al., 2008), as well as the therapeutic efficacy of SRIF analogs.

Although few data exist about the selected antiproliferative effect of SRIF and related agonists on PCa model systems (Bogden et al. 1990; Brevini et al., 1993), these studies did not fully address the potential and selective role of the different sst $_{\mathrm{s}}$ in $\mathrm{PCa}$ progression. Thus, we evaluated the effects of selective SRIF agonists on LNCaP cell growth. BIM-23244 (the sst $_{2} / \mathrm{sst}_{5}$ preferential compound) and lanreotide (a sst $_{2}$ preferential compound with a moderate affinity for $\mathrm{sst}_{5}$ ) were significantly more potent in inhibiting $\mathrm{LNCaP}$ cell proliferation than the mono-specific sst $_{2}$ - and sst ${ }_{5}$-preferring analogs (BIM-23120 and BIM23206 , respectively), tested either alone or in combination. These differences between the mono- and the bi-specific compounds might be due to the ability of BIM-23244 and, to a lesser extent, of lanreotide to stabilize or enhance $\mathrm{sst}_{2} / \mathrm{sst}_{5}$ dimerization (corresponding to the amount of sst $_{2}$ co-immunoprecipitated with sst $_{5}$ ), as suggested by the increased stabilization (and/or number) of the $\mathrm{sst}_{2} / \mathrm{sst}_{5}$ dimers on the cell membrane after treatment with these compounds (Fig. 4B). This finding is in agreement with the ability of sst $t_{5}$ in regulating $\mathrm{sst}_{2}$ trafficking (Sharif et al., 2007) and/or its retain within the membrane (Ben-Shlomo et al., 2005), and might also explain the efficacy of BIM-23244 over a wider dose range compared with lanreotide. Moreover, in contrast with the reversibility of the effect observed with lanreotide, the increased activity of BIM-23244 was not counteracted by the sst $_{2}$ antagonist, BIM-23267. Furthermore, in LNCaP cells, BIM-23244, in agreement with previous observations in other cell systems, such as human pituitary adenoma and NSCLC Calu-6 cells (Ferone et al., 2005; Saveanu et al., 2001) closely mimicked the effects of native SRIF. Differently from human medullary thyroid TT cells, where BIM-23206 completely counteracts the suppressive activity of BIM-23120 (Zatelli et al., 2001), in LNCaP cells the effects of these agonists were both directed toward a significant antiproliferative effect, suggesting not only tissue-specific activity, but also a tissue-specific interactions between these two sst $\mathrm{s}_{\mathrm{s}}$. The different cross-talk between $\mathrm{sst}_{\mathrm{s}}$ in different districts may partially explain the functional tissue-specificity of an ubiquitous hormone such as SRIF. Dose-response experiments showed that the sst ${ }_{1}$-preferential compound BIM-23296 negatively affected cell proliferation, with a greater potency than $\mathrm{sst}_{2}$ and $\mathrm{sst}_{5}$ agonist, possibly due to $\mathrm{sst}_{1}$ upregulation and/or to a low agonist-induced internalization of sst $_{1}$ (Hofland et al., 2003; Nouel et al., 1997; Sarret et al., 1999). Notably, sst ${ }_{1}$ was found to be the most abundantly expressed SRIF receptor in PCa tissue (Halmos et al., 2000; Reubi et al., 1995). The results obtained with the $\mathrm{sst}_{1} / \mathrm{sst}_{2}$-preferential agonist BIM-23704 suggest that the simultaneous recruitment of these two receptors, although able to stabilize $\mathrm{sst}_{1} / \mathrm{sst}_{2}$ dimerization, is less effective in terms of antiproliferation and fully sensitive to specific $\mathrm{sst}_{2}$ antagonism, than $\mathrm{sst}_{2} / \mathrm{sst}_{5}$ activation.

Moreover. our data suggest that the antiproliferative effects of these SRIF agonists on $\mathrm{LNCaP}$ cells, may, at least in part, result from cell cycle arrest in the $\mathrm{G}_{0} / \mathrm{G}_{1}$ phase, as suggested by the observed up-regulation of the cyclin-dependent kinase inhibitors p27 and p21 and the inhibition of cyclin E. Along with these direct actions on cell cycle, SRIF may also regulate tumor growth by indirect action suppressing the secretion of growth-promoting hormones and growth factors (Lamberts et al., 2002). In addition to systemic suppression of the GH-IGF-I axis, SRIF analogs may also affect paracrine and autocrine IGF-I loops within the tumoral prostatic tissue (Pietrzkowski et al., 1993). LNCap cells have been shown to secrete low amounts of IGF-I and IGF-II and to express some IGF-binding proteins (IGFBPs), with prevalence of IGFBP-3 (Kawada et al., 2006). Interestingly, we found that 
treatment with SRIF agonists markedly affected the secretory profile of the IGF system, consequently inhibiting cell growth.

Our study also demonstrated the ability of exogenous IGF-I, at variance to IGF-II, to counteract the inhibitory effect on cell proliferation of all SRIF analogs tested. This is in agreement with the finding of a mitogenic effect of IGF-I alone on LNCaP cells, which is not evident after incubation with IGF-II. These findings could be explained by the different relative amounts of IGFBP-3 (which has higher binding affinity for IGF-I with respect to IGF-II) and IGFBP-2 (which has higher binding affinity for IGF-II with respect to IGF-I) present in LNCaP conditioned medium (data not shown). In fact, since IGFBP-3 is almost totally proteolysed by PSA secreted by LNCaP cells, the free form of IGF-I may increase, leading to an enhanced IGF-I bioactivity. On the contrary, IGFBP-2, which is present in high concentration, leads to a prevalent inhibition of IGF-II effect.

Indirect confirmation of this hypothesis comes from the clinical experience where a positive correlation between IGF-I and IGFBP-3 and no correlation between IGF-II and IGFBP-2 and prostate cancer was observed (Roddam et al., 2008).

In particular, IGF-I secretion was dramatically reduced by lanreotide and BIM-23244 ( sst $_{2} /$ sst $_{5}$ agonists), BIM-23926 ( sst $_{1}$ agonist), BIM-23120 ( sst $_{2}$ agonist), BIM-23206 ( sst $_{5}$ agonist), but not BIM-23704 ( sst $_{1} / \mathrm{sst}_{2}$ agonist). Moreover, $\mathrm{sst}_{2}$ antagonist BIM-23627 abolished the stimulatory effect of BIM-23704 and the inhibitory effect of lanreotide and BIM-23244. IGF-II secretion was also markedly reduced by all SRIF agonists except BIM23120. Such effects were counteracted by BIM-23627 only with bi-specific compounds, further emphasizing the need of simultaneous recruitment of both receptors. SRIF agonistinduced reduction of IGF-I/II levels may impair the activity of the autocrine loop, thereby contributing to growth inhibition, although in the present study we could not establish the extent of the specific contribution of reduced/increased IGFs to this phenomenon.

Deglycosylated rh-IGFBP-3 underwent an extensive proteolytic cleavage in untreated cells, possibly due to the activity of PSA, which is secreted by these cells and shows specific proteolytic activity toward IGFBP-3 (Birnbaum et al., 1994). Interestingly, all compounds increased the amount of intact rh-IGFBP-3, probably due to a reduced PSA production (Ruscica et al., unpublished data), whereas treatment with the sst $_{2}$ antagonist BIM-23627, alone or in combination with mono- or bi-specific sst $_{2}$ analogs, abolished this effect. SRIF agonist-induced increase of intact rh-IGFBP-3 might reduce free IGF-I availability resulting in a further suppression of paracrine and autocrine IGF-I loop.

The present study highlights that $\mathrm{sst}_{\mathrm{s}}$ receptor modulation may lead to inhibition of androgen-dependent PCa cell growth through a specific receptor isoform involvement and dimerization. Among all tested compounds, a particular relevance emerged for sst $_{1^{-}}$and $\mathrm{sst}_{2} / \mathrm{sst}_{5}$-preferring agonists, which, at least in terms of antiproliferative effects, more closely mimicked the activity profile of SRIF. Thus, these results expand the role of sst $_{\mathrm{s}}$ receptors as potential therapeutic targets for androgen-dependent PCa. The development of SRIF analogs with high affinity for each sst, as well as of pan-ligands and bi-specific compounds (Boerlin

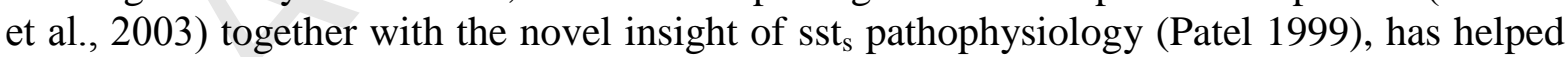
to better understand the role of the sst $_{\mathrm{s}}$ depending on different biological activity and on differential expression in human prostatic tissue (Zatelli et al., 2001). Moreover, this is the first report that provides strong evidence for an inhibitory role of $s t_{1}$ activation on PCa cell proliferation, suggesting that SRIF agonists with enhanced $s t_{1}$ affinity and selectivity may have great potentiality as pharmacological tools for at least androgen-dependent PCa treatment. In addition, the antiproliferative effect of sst $_{1}$ and sst $_{5}$ mono-specific agonists may be due, at least in part, to the inhibition of IGF-I secretion.

In conclusion, our results show that $\mathrm{sst}_{1}$ up-regulation and sst $_{1}$-driven antiproliferative/antisecretive actions represent a set of complementary favorable events in terms of antiproliferative activity. Moreover, the bi-specific sst $_{2} /$ sst $_{5}$-preferential compound BIM-23244-promoted enhancing of $\mathrm{sst}_{2} / \mathrm{sst}_{5}$ dimer stabilization and thereby potential regulation of $\mathrm{sst}_{2}$ trafficking, and modulation of IGF secretion, resulting in a marked 
1 antiproliferative effect. Conversely, activation of $\mathrm{sst}_{1} / \mathrm{sst}_{2}$ appears however less effective than 2 that of either $\mathrm{sst}_{1}$ alone or $\mathrm{sst}_{2} / \mathrm{sst}_{5}$. These observations represent pharmacological events that 3 may deserve further exploitation at the experimental and possibly clinical levels, also in the 4 context of established cancer therapies, like taxanes and other chemotherapeutic agents.

5

\section{ACKNOWLEDGEMENTS}

7

8 This study was supported by grants from Ministero dell'Università e della Ricerca (PRIN $92005 n^{\circ} 2002067251-001$ to F.M.; Fondo per gli Investimenti della Ricerca di Base 10 nRBAU019TMF_001 to F.M.) and Università degli Studi di Milano (FIRST 2007 and PUR 112008 to P.M.). The expert technical collaboration of Ms. Paola Assi and Giovanna Miccichè 12 is gratefully acknowledged. 


\section{REFERENCES}

Ben-Shlomo, A., Wawrowsky, K.A., Proekt, I., Wolkenfeld, N.M., Ren, S.G., Taylor, J., Culler, M.D. and Melmed, S. (2005). Somatostatin receptor type 5 modulates somatostatin receptor type 2 regulation of adrenocorticotropin secretion. J Biol Chem 280, 24011-21.

Birnbaum, R.S., Ware, J.L. and Plymate, S.R. (1994). Insulin-like growth factor-binding protein-3 expression and secretion by cultures of human prostate epithelial cells and stromal fibroblasts. $\mathrm{J}$ Endocrinol 141, 535-40.

Boerlin, V., van der Hoek, J., Beglinger, C., Poon, K.W., Hartmann, S., Dutreix, C., Kovarik, J.M., Bruns, C., Weckbecker, G., Lewis, I., Schnieper, P., Hofland, L.J. and Lamberts, S.W. (2003). New insights on SOM230, a universal somatostatin receptor ligand. J Endocrinol Invest 26, 14-6.

Bogden, A.E., Taylor, J.E., Moreau, J.P. and Coy, D.H. (1990). Treatment of R-3327 prostate tumors with a somatostatin analogue (somatuline) as adjuvant therapy following surgical castration. Cancer Res 50, 2646-50.

Brevini, T.A., Bianchi, R. and Motta, M. (1993). Direct inhibitory effect of somatostatin on the growth of the human prostatic cancer cell line LNCaP: possible mechanism of action. J Clin Endocrinol Metab 77, 626-31.

Coy, D.H. and Murphy, W.A. (1990). Linear somatostatin analogs. U.S., WO 90/12811.

degli Uberti, E.C., Zatelli, M.C. and Culler, M.D. (2002). Method of modulating the proliferation of medullary thyroid carcinoma cells. U.S., WO 02/070555.

Dizeyi, N., Konrad, L.K., Bjartell, A., Wu, H., Gadaleanu, V., Hansson, J., Helboe, L. and Abrahamsson, P.A. (2002). Localization and mRNA expression of somatostatin receptor subtypes in human prostatic tissue and prostate cancer cell lines. Urologic Oncology 7, 91-98.

Djavan, B., Waldert, M., Seitz, C. and Marberger, M. (2001). Insulin-like growth factors and prostate cancer. World J Urol 19, 225-33.

Djavan, B. (2007). Editorial. Prostate cancer update. BJU Int 100 Suppl 2, 1.

Djordjijevic, D., Zhang, J., Priam, M., Viollet, C., Gourdji, D., Kordon, C. and Epelbaum, J. (1998). Effect of 17beta-estradiol on somatostatin receptor expression and inhibitory effects on growth hormone and prolactin release in rat pituitary cell cultures. Endocrinology 139, 2272-7. 
1 Erten, C., Karaca, B., Kucukzeybek, Y., Gorumlu, G., Cengiz, E., Gul, M.K., Atmaca, H., Uzunoglu, S., Karabulut, B., Sanli, U.A. and Uslu, R. (2009). Regulation of growth factors in hormone- and drug-resistant prostate cancer cells by synergistic combination of docetaxel and octreotide. BJU Int,

Ferone, D., Arvigo, M., Semino, C., Jaquet, P., Saveanu, A., Taylor, J.E., Moreau, J.P., Culler, M.D., Albertelli, M., Minuto, F. and Barreca, A. (2005). Somatostatin and dopamine receptor expression in lung carcinoma cells and effects of chimeric somatostatin-dopamine molecules on cell proliferation. Am J Physiol Endocrinol Metab 289, E1044-50.

Figg, W.D., Thibault, A., Cooper, M.R., Reid, R., Headlee, D., Dawson, N., Kohler, D.R., Reed, E. and Sartor, O. (1995). A phase I study of the somatostatin analogue somatuline in patients with metastatic hormone-refractory prostate cancer. Cancer 75, 2159-64.

Gordon, T.D., Morgan, B.A. and Culler, M.D. (2003). Somatostatin analogs and uses thereof. U.S., WO 03/045320.

Halmos, G., Schally, A.V., Sun, B., Davis, R., Bostwick, D.G. and Plonowski, A. (2000). High expression of somatostatin receptors and messenger ribonucleic acid for its receptor subtypes in organ-confined and locally advanced human prostate cancers. J Clin Endocrinol Metab 85, 256471.

Hejna, M., Schmidinger, M. and Raderer, M. (2002). The clinical role of somatostatin analogues as antineoplastic agents: much ado about nothing? Ann Oncol 13, 653-68.

Hofland, L.J. and Lamberts, S.W. (2003). The pathophysiological consequences of somatostatin receptor internalization and resistance. Endocr Rev 24, 28-47.

Horoszewicz, J.S., Leong, S.S., Chu, T.M., Wajsman, Z.L., Friedman, M., Papsidero, L., Kim, U., Chai, L.S., Kakati, S., Arya, S.K. and Sandberg, A.A. (1980). The LNCaP cell line--a new model for studies on human prostatic carcinoma. Prog Clin Biol Res 37, 115-32.

Horoszewicz, J.S., Leong, S.S., Kawinski, E., Karr, J.P., Rosenthal, H., Chu, T.M., Mirand, E.A. and Murphy, G.P. (1983). LNCaP model of human prostatic carcinoma. Cancer Res 43, 1809-18.

Kalkner, K.M., Nilsson, S. and Westlin, J.E. (1998). [111In-DTPA-D-Phe1]-octreotide scintigraphy in patients with hormone-refractory prostatic adenocarcinoma can predict therapy outcome with octreotide treatment: a pilot study. Anticancer Res 18, 513-6. 
1 Kawada, M., Inoue, H., Masuda, T. and Ikeda, D. (2006). Insulin-like growth factor I secreted from prostate stromal cells mediates tumor-stromal cell interactions of prostate cancer. Cancer Res 66, 4419-25.

Khan, I.U. and Beck-Sickinger, A.G. (2008). Targeted tumor diagnosis and therapy with peptide hormones as radiopharmaceuticals. Anticancer Agents Med Chem 8, 186-99.

Kimura, N., Takamatsu, N., Yaoita, Y., Osamura, R.Y. and Kimura, N. (2008). Identification of transcriptional regulatory elements in the human somatostatin receptor sst2 promoter and regions including estrogen response element half-site for estrogen activation. J Mol Endocrinol 40, 7591.

Krantic, S., Goddard, I., Saveanu, A., Giannetti, N., Fombonne, J., Cardoso, A., Jaquet, P. and Enjalbert, A. (2004). Novel modalities of somatostatin actions. Eur J Endocrinol 151, 643-55.

Lamberts, S.W., van der Lely, A.J. and Hofland, L.J. (2002). New somatostatin analogs: will they fulfil old promises? Eur J Endocrinol 146, 701-5.

Liu, Z., Marquez, M., Nilsson, S. and Holmberg, A.R. (2008). Incubation with somatostatin, 5-aza decitabine and trichostatin up-regulates somatostatin receptor expression in prostate cancer cells. Oncol Rep 20, 151-4.

Lo Nigro, C., Maffi, M., Fischel, J.L., Formento, P., Milano, G. and Merlano, M. (2008). The combination of docetaxel and the somatostatin analogue lanreotide on androgen-independent docetaxel-resistant prostate cancer: experimental data. BJU Int,

Maulard, C., Richaud, P., Droz, J.P., Jessueld, D., Dufour-Esquerre, F. and Housset, M. (1995). Phase I-II study of the somatostatin analogue lanreotide in hormone-refractory prostate cancer. Cancer Chemother Pharmacol 36, 259-62.

Nickerson, T., Chang, F., Lorimer, D., Smeekens, S.P., Sawyers, C.L. and Pollak, M. (2001). In vivo progression of LAPC-9 and LNCaP prostate cancer models to androgen independence is associated with increased expression of insulin-like growth factor I (IGF-I) and IGF-I receptor (IGF-IR). Cancer Res 61, 6276-80.

Nilsson, S., Reubi, J.C., Kalkner, K.M., Laissue, J.A., Horisberger, U., Olerud, C. and Westlin, J.E. (1995). Metastatic hormone-refractory prostatic adenocarcinoma expresses somatostatin receptors and is visualized in vivo by [111In]-labeled DTPA-D-[Phe1]-octreotide scintigraphy. 
Cancer Res 55, 5805s-5810s.

Nouel, D., Gaudriault, G., Houle, M., Reisine, T., Vincent, J.P., Mazella, J. and Beaudet, A. (1997). Differential internalization of somatostatin in COS-7 cells transfected with SST1 and SST2 receptor subtypes: a confocal microscopic study using novel fluorescent somatostatin derivatives. Endocrinology 138, 296-306.

Patel, Y.C. (1999). Somatostatin and its receptor family. Front Neuroendocrinol 20, 157-98.

Pietrzkowski, Z., Mulholland, G., Gomella, L., Jameson, B.A., Wernicke, D. and Baserga, R. (1993). Inhibition of growth of prostatic cancer cell lines by peptide analogues of insulin-like growth factor 1. Cancer Res 53, 1102-6.

Plonowski, A., Schally, A.V., Nagy, A., Sun, B. and Szepeshazi, K. (1999). Inhibition of PC-3 human androgen-independent prostate cancer and its metastases by cytotoxic somatostatin analogue AN238. Cancer Research 59, 1947-1953.

Reubi, J.C. (2003). Peptide receptors as molecular targets for cancer diagnosis and therapy. Endocr Rev 24, 389-427.

Reubi, J.C. (2004). Somatostatin and other Peptide receptors as tools for tumor diagnosis and treatment. Neuroendocrinology 80 Suppl 1, 51-6.

Reubi, J.C., Waser, B., Schaer, J.C. and Laissue, J.A. (2001). Somatostatin receptor sst1-sst5 expression in normal and neoplastic human tissues using receptor autoradiography with subtypeselective ligands. Eur J Nucl Med 28, 836-46.

Reubi, J.C., Waser, B., Schaer, J.C. and Markwalder, R. (1995). Somatostatin receptors in human prostate and prostate cancer. J Clin Endocrinol Metab 80, 2806-14.

Roddam. A.W., Allen, N.E., Appleby. P., Key. T.J., Ferrucci. L., Carter. H.B., Metter. E.J., Chen. C., Weiss. N.S., Fitzpatrick. A., Hsing. A.W., Lacey. J.V. Jr., Helzlsouer. K., Rinaldi. S., Riboli. E., Kaaks. R., Janssen. J.A., Wildhagen. M.F., Schröder. F.H., Platz. E.A., Pollak. M., Giovannucci. E., Schaefer. C., Quesenberry. C.P. Jr., Vogelman. J.H., Severi. G., English. D.R., Giles. G.G., Stattin. P., Hallmans. G., Johansson. M., Chan. J.M., Gann. P., Oliver. S.E., Holly. J.M., Donovan. J., Meyer. F., Bairati. I., and Galan. P. (2008). Insulin-like Growth Factors, Their Binding Proteins, and Prostate Cancer Risk: Analysis of Individual Patient Data from 12 Prospective Studies. Ann Intern Med 149, 461-W88. 
1 Ruscica, M., Dozio, E., Boghossian, S., Bovo, G., Martos Riano, V., Motta, M. and Magni, P. (2006). Activation of the Y1 receptor by neuropeptide y regulates the growth of prostate cancer cells. Endocrinology 147, 1466-73.

Russell, P.J., Bennett, S. and Stricker, P. (1998). Growth factor involvement in progression of prostate cancer. Clin Chem 44, 705-23.

Sarret, P., Nouel, D., Dal Farra, C., Vincent, J.P., Beaudet, A. and Mazella, J. (1999). Receptormediated internalization is critical for the inhibition of the expression of growth hormone by somatostatin in the pituitary cell line AtT-20. J Biol Chem 274, 19294-300.

Saveanu, A., Gunz, G., Dufour, H., Caron, P., Fina, F., Ouafik, L., Culler, M.D., Moreau, J.P., Enjalbert, A. and Jaquet, P. (2001). Bim-23244, a somatostatin receptor subtype 2- and 5selective analog with enhanced efficacy in suppressing growth hormone (GH) from octreotideresistant human GH-secreting adenomas. J Clin Endocrinol Metab 86, 140-5.

Sharif, N., Gendron, L., Wowchuk, J., Sarret, P., Mazella, J., Beaudet, A. and Stroh, T. (2007). Coexpression of somatostatin receptor subtype 5 affects internalization and trafficking of somatostatin receptor subtype 2. Endocrinology 148, 2095-105.

Sinisi, A.A., Bellastella, A., Prezioso, D., Nicchio, M.R., Lotti, T., Salvatore, M. and Pasquali, D. (1997). Different expression patterns of somatostatin receptor subtypes in cultured epithelial cells from human normal prostate and prostate cancer. J Clin Endocrinol Metab 82, 2566-9.

Taylor, J.E., Theveniau, M.A., Bashirzadeh, R., Reisine, T. and Eden, P.A. (1994). Detection of somatostatin receptor subtype 2 (SSTR2) in established tumors and tumor cell lines: evidence for SSTR2 heterogeneity. Peptides 15, 1229-36.

Tejeda, M., Gaal, D., Hullan, L., Hegymegi-Barakonyi, B. and Keri, G. (2006). Evaluation of the antitumor efficacy of the somatostatin structural derivative TT-232 on different tumor models. Anticancer Res 26, 3477-83.

Thakur, M.L., Kolan, H., Li, J., Wiaderkiewicz, R., Pallela, V.R., Duggaraju, R. and Schally, A.V. (1997). Radiolabeled somatostatin analogs in prostate cancer. Nucl Med Biol 24, 105-13.

Tressel, T.J., Tatsuno, G.P., Spratt, K. and Sommer, A. (1991). Purification and characterization of human recombinant insulin-like growth factor binding protein 3 expressed in Chinese hamster ovary cells. Biochem Biophys Res Commun 178, 625-33. 
Viguerie, N., Esteve, J.P., Susini, C., Logsdon, C.D., Vaysse, N. and Ribet, A. (1987). Dexamethasone effects on somatostatin receptors in pancreatic acinar AR4-2J cells. Biochem Biophys Res Commun 147, 942-8.

Visser-Wisselaar, H.A., Hofland, L.J., van Uffelen, C.J., van Koetsveld, P.M. and Lamberts, S.W. (1996). Somatostatin receptor manipulation. Digestion 57 Suppl 1, 7-10.

Zapata, P.D., Ropero, R.M., Valencia, A.M., Buscail, L., Lopez, J.I., Martin-Orozco, R.M., Prieto, J.C., Angulo, J., Susini, C., Lopez-Ruiz, P. and Colas, B. (2002). Autocrine regulation of human prostate carcinoma cell proliferation by somatostatin through the modulation of the $\mathrm{SH} 2$ domain containing protein tyrosine phosphatase (SHP)-1. J Clin Endocrinol Metab 87, 915-26.

Zatelli, M.C., Tagliati, F., Taylor, J.E., Rossi, R., Culler, M.D. and degli Uberti, E.C. (2001). Somatostatin receptor subtypes 2 and 5 differentially affect proliferation in vitro of the human medullary thyroid carcinoma cell line tt. J Clin Endocrinol Metab 86, 2161-9.

\section{FIGURE LEGENDS}

Fig. 1. RT-PCR and Western blot analysis of sst $_{1-5}$ expression in LNCaP cells. A) Total RNA extracts from LNCaP cells, non-functional pituitary adenoma (NFPA - sst 1 -2A-3-5 positive control) and benign prostatic hyperplasia (BPH - sst 4 positive control) samples were subjected to RT-PCR analysis using oligoprimers specific for $\mathrm{sst}_{1-5}$ and $18 \mathrm{~s}$ ribosomal protein (internal control); B) Cell extracts were subjected to Western blot analysis using antisera against sst $_{1}$, $\mathrm{sst}_{2 \mathrm{~A}}, \mathrm{sst}_{3}, \mathrm{sst}_{4}$ and $\mathrm{sst}_{5}$. The human Calu-6 NSCLC cell line and a sample of benign prostatic hyperplasia $(\mathrm{BPH})$ were included as positive controls.

Fig. 2. Influence of different culture conditions on sst $_{1}$ and sst ${ }_{3}$ gene and protein levels of expression in LNCaP cells. LNCaP cells were cultured either with 10\% FBS (standard culture conditions) or with $2 \%$ FBS (experimental culture conditions) for $48 \mathrm{~h} . \mathrm{A}$ ) Semiquantitative RT-PCR analysis of $\mathrm{sst}_{1}$ and $\mathrm{sst}_{3}$ gene expression. Parallel amplification of $18 \mathrm{~s}$ ribosomal protein mRNA served as internal control. $B$ ) Real-time RT-PCR analysis of $\mathrm{sst}_{1}$ and $\mathrm{sst}_{3}$ gene expression. Data are presented as mean fold increment $\pm \mathrm{SEM}, \mathrm{n}=3$, **P $<0.01$ vs. $10 \%$ FBS. C) Western blot analysis of sst $_{1}$ and $\mathrm{sst}_{3}$ in protein extracts from $\mathrm{LNCaP}$ cells.

Fig. 3. Effects of SRIF analogs and sst ${ }_{2}$-selective antagonist BIM-23627 on BrdUincorporation on LNCaP cells. Mean dose-response growth-inhibition curves obtained with LNCaP cells cultured in 96-well plates for $48 \mathrm{~h}$ with: A) lanreotide (Lan), bi-specific sst $_{2} /$ sst $_{5}$-preferential compound BIM-23244 and SRIF; $B$ ) sst $_{2}$-preferential compound BIM23120, sst 5 -preferential compound BIM-23206 and the combination of both; C) sst $_{1}$ preferential compound BIM-23296 and bi-specific sst $_{1} /$ sst $_{2}$-preferential compound BIM23704; D) Lan $\left(10^{-7}-10^{-11} \mathrm{M}\right.$ ) with or without BIM-23627 (Ant; $10^{-7} \mathrm{M}$ ) and $E$ ) BIM-23704 with or without Ant $\left(10^{-7} \mathrm{M}\right)$. Control wells were treated with vehicle solution. Results are expressed as mean $( \pm \mathrm{SE}) \%$ growth inhibition $v s$. control $(-), \mathrm{n}=8$. 
1 Fig. 4. $S s t_{1} / s s t_{2}$, sst $t_{2} / s s t_{5}$ heterodimerization and effect of SRIF analogs on rh-IGFBP-3 proteolytic activity of $\mathrm{LNCaP}$ cell conditioned medium. To assess the stabilization of $\mathrm{sst}_{1} / \mathrm{sst}_{2-}$ and $\mathrm{sst}_{2} / \mathrm{sst}_{5}$-driven heterodimerization, membrane preparations from LNCaP cells were, respectively: A) immunoprecipitated with anti-sst ${ }_{2}$ antibody and immunoblotted with anti-sst ${ }_{1}$ antibody. The band of $60 \mathrm{kDa}$ corresponds to the $\mathrm{sst}_{1}$ co-immunoprecipitated with $\mathrm{sst}_{2} ; B$ ) immunoprecipitated with anti-sst ${ }_{5}$ antibody and immunoblotted with anti-sst ${ }_{2}$ antibody. The band of $45 \mathrm{kDa}$ corresponds to the $\mathrm{sst}_{2}$ co-immunoprecipitated with $\mathrm{sst}_{5}$; $C$ ) Exogenous rhIGFBP-3 was incubated for $5 \mathrm{~h}$ at $37^{\circ} \mathrm{C}$ with conditioned media from $\mathrm{LNCaP}$ cultured in the presence or absence of different SRIF analogs $\left(10^{-9} \mathrm{M}\right)$ and $\mathrm{sst}_{2}$-selective antagonist BIM$23627\left(10^{-7} \mathrm{M}\right)$. As internal control exogenous rh-IGFBP-3 was incubated only with vehicle (PBS). The amount of residual intact rh-IGFBP-3 was visualized by immunoblotting. Lanreotide and BIM-23627 are indicated as Lan and Ant, respectively. IP: immunoprecipitation; WB: Western blot

Fig. 5. Effect of SRIF analogs treatment on protein expression of $p 27^{\text {KipI }}, p 21$ and cyclin $E$ in LNCaP cells. As detailed in the "Materials and Methods" section, the cells were treated for $48 \mathrm{~h}$ with SRIF analogs at the concentration of $10^{-9} \mathrm{M}$ and vehicle alone (control). Total cell lysates were prepared for immunoblot analysis. The values above the figures represent the relative density of each band normalized to tubulin. The data shown here are from a representative experiment repeated three times with similar results. 
Table 1. SRIF and SRIF analogs: human somatostatin receptor subtype (sst $\left.{ }_{1-5}\right)$ specificity $\left(\mathrm{IC}_{50}-\mathrm{nM}\right)$

\begin{tabular}{lccccc}
\multicolumn{1}{c}{ compound } & sst $_{\mathbf{1}}$ & $\mathbf{s s t}_{\mathbf{2}}$ & $\mathbf{s s t}_{\mathbf{3}}$ & $\mathbf{s s t}_{\mathbf{4}}$ & $\mathbf{s s t}_{\mathbf{5}}$ \\
\hline SRIF & 1.95 & 0.25 & 1.2 & 1.77 & 1.41 \\
Lanreotide & 2129 & 0.75 & 98 & 1826 & 12.7 \\
BIM-23244 & 1020 & 0.29 & 133 & $>1000$ & 0.67 \\
BIM-23120 & 1000 & 0.34 & 412 & 1000 & 213.5 \\
BIM-23206 & 1152 & 166 & 1000 & 1618 & 2.4 \\
BIM-23926 & 3.6 & $>1000$ & 1000 & 833 & 788 \\
BIM-23704 & 6.25 & 1.37 & 43.2 & 1000 & 115 \\
BIM-23627 & 2757 & 6.4 & 44 & 423 & 86.5 \\
\hline
\end{tabular}


Table 2. Effect of treatments with SRIF analogs on IGF-I and IGF-II secretion by LNCaP cells

\begin{tabular}{|c|c|c|c|c|c|c|c|c|c|c|}
\hline & Lan & $\begin{array}{c}\text { Lan }+ \\
\text { Ant }\end{array}$ & BIM-23244 & $\begin{array}{c}\text { BIM-23244 + } \\
\text { Ant }\end{array}$ & BIM-23704 & $\begin{array}{c}\text { BIM-23704 + } \\
\text { Ant }\end{array}$ & BIM-23120 & $\begin{array}{c}\text { BIM-23120 + } \\
\text { Ant }\end{array}$ & BIM-23206 & BIM-23926 \\
\hline IGF-I & $-36.2 \pm 2.3$ & $+10.8 \pm 5.2$ & $-91.1 \pm 0.7$ & $+21.5 \pm 2.0$ & $+33.5 \pm 2.4$ & $+3.8 \pm 2.4$ & $-75.9 \pm 1.2$ & $-50.6 \pm 1.1$ & $-49.3 \pm 1.4$ & $-85 \pm 1.7$ \\
\hline IGF-II & $-68.1 \pm 0.9$ & $-81.1 \pm 0.6$ & $-59.2 \pm 0.4$ & $+8.10 \pm 1.3$ & $-43.3 \pm 1.1$ & $+12 \pm 1.7$ & $+19.2 \pm 1.4$ & $+72.9 \pm 1.0$ & $-85.8 \pm 1.2$ & $-68.5 \pm 1.4$ \\
\hline
\end{tabular}

Experiments were conducted in triplicate and the results expressed as mean $(\%$ variation $) \pm \mathrm{SD}$ (basal medium content; IGF-I $=25 \mathrm{ng} / \mathrm{mL}$; IGF-II $=38.2 \mathrm{ng} / \mathrm{mL})$

Lan, lanreotide; Ant, BIM-23627; IGF, insulin-like growth factor 
Table 3. Effect of $48 \mathrm{~h}$-treatment with SRIF agonists, IGF-I and IGF-II on LNCaP cell proliferation

\begin{tabular}{|c|c|c|c|c|c|c|c|c|c|c|c|}
\hline $\mathrm{C}$ & IGF-I & Lan & $\begin{array}{l}\text { Lan + } \\
\text { IGF-I }\end{array}$ & BIM-23244 & $\begin{array}{c}\text { BIM-23244 + } \\
\text { IGF-I }\end{array}$ & BIM-23120 & $\begin{array}{c}\text { BIM-23120 + } \\
\text { IGF-I }\end{array}$ & BIM-23206 & $\begin{array}{c}\text { BIM-23206 + } \\
\text { IGF-I }\end{array}$ & BIM23926 & $\begin{array}{c}\text { BIM23926 + } \\
\text { IGF-I }\end{array}$ \\
\hline & $18.5 \pm 3.5$ & $-23.1 \pm 2.9$ & $-4.1 \pm 0.9$ & $-20.8 \pm 1.8$ & $-0.9 \pm 3.1$ & $-12.2 \pm 1.8$ & $13.3 \pm 8.3$ & $-12 \pm 2.0$ & $9.5 \pm 6.7$ & $-18.6 \pm 3.4$ & $-0.7 \pm 1.3$ \\
\hline
\end{tabular}

\begin{tabular}{|c|c|c|c|c|c|c|c|c|c|c|c|}
\hline C & IGF-II & Lan & $\begin{array}{c}\text { Lan + IGF- } \\
\text { II }\end{array}$ & BIM-23244 & $\begin{array}{c}\text { BIM-23244 + } \\
\text { IGF-II }\end{array}$ & BIM-23704 & $\begin{array}{c}\text { BIM-23704+ } \\
\text { IGF-II }\end{array}$ & $\begin{array}{c}\text { BIM-23206 } \\
\text { BIM-23206 + } \\
\text { IGF-II }\end{array}$ & $\begin{array}{c}\text { BIM23926 } \\
\text { BIM23926 + } \\
\text { IGF-II }\end{array}$ \\
\cline { 2 - 9 } & $2.4 \pm 7.55$ & $-23.1 \pm 2.9$ & $-16.6 \pm 3.4$ & $-20.8 \pm 1.8$ & $-17.5 \pm 3.5$ & $-13.1 \pm 0.9$ & $-9.5 \pm 0.5$ & $-12 \pm 2.0$ & $-8.8 . \pm 1.1$ & $-13.3 \pm 1.9$ & $-9.1 \pm 2.9$ \\
\hline
\end{tabular}

48-h treatment experiments were conducted in duplicate $($ each $\mathrm{n}=8)$ and the results expressed as mean (\% variation $) \pm \mathrm{SEM}$.

Lan, lanreotide; IGF-I and -II, insulin-like growth factor I and II 
Fig. 1

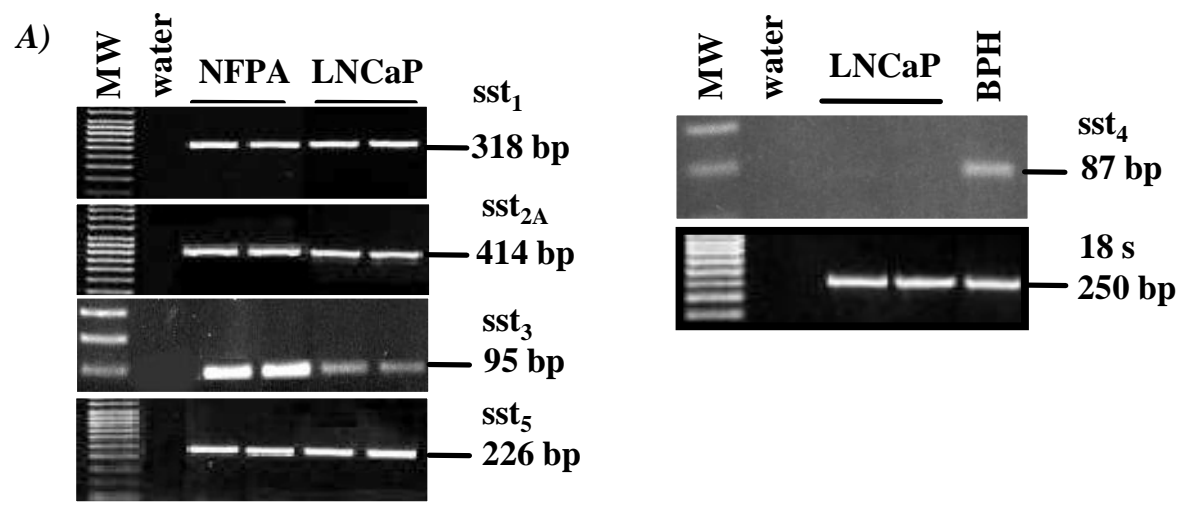

B)
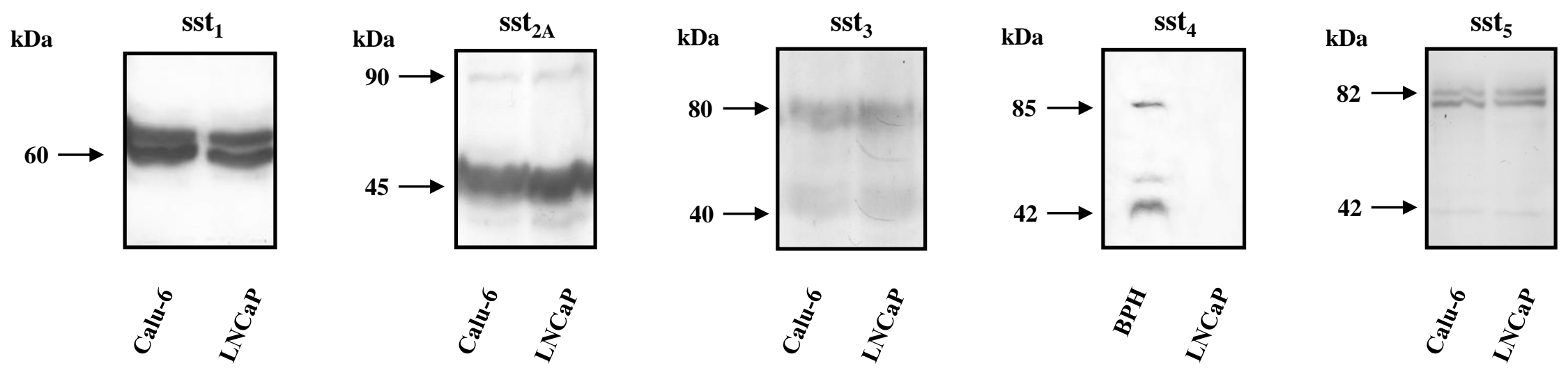
Fig. 2

A)
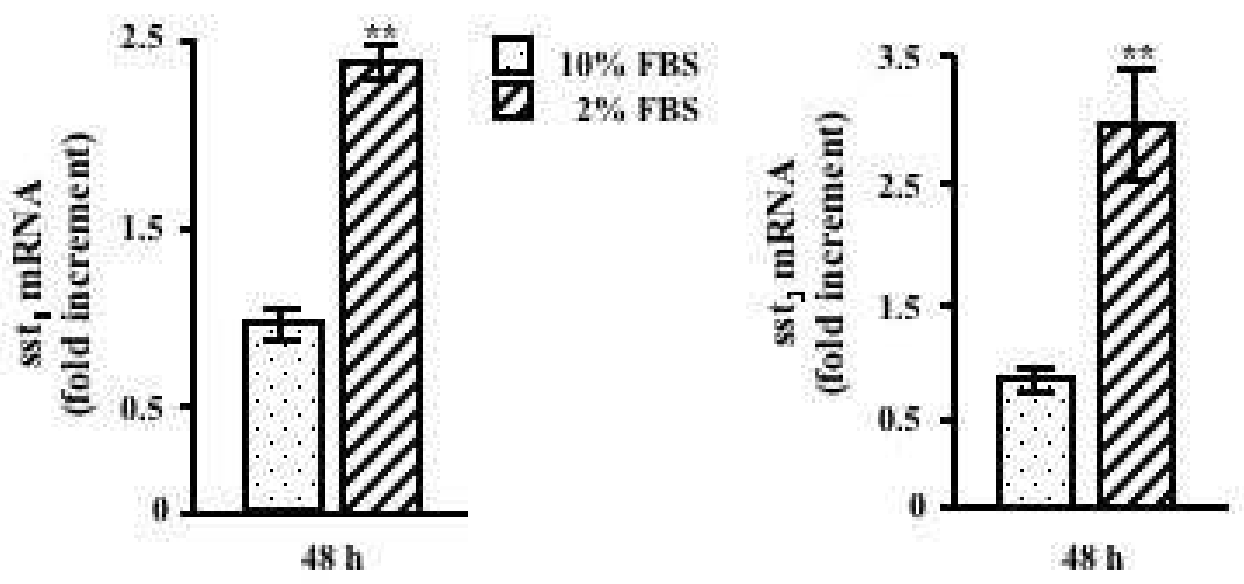

B)
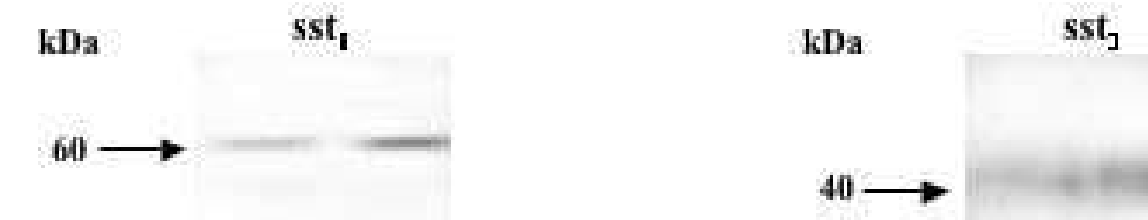

$\begin{array}{llr}\text { FBS (\%) } & 10 & 2 \\ \text { TIME (h) } & 48 & 48\end{array}$

FBS (\%) 10 2

TIME (h) $\quad 48 \quad 48$ 
Fig. 3

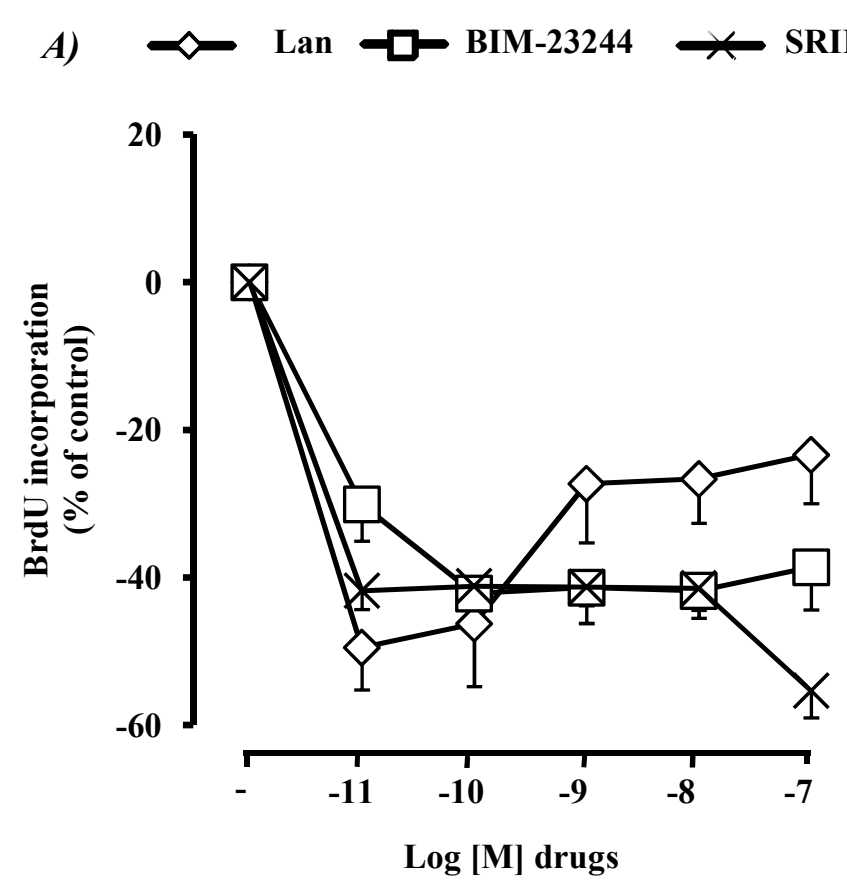

D) $\sim$ Lan $-\square-$ Lan + Ant $-\Delta-\triangle$ Ant.

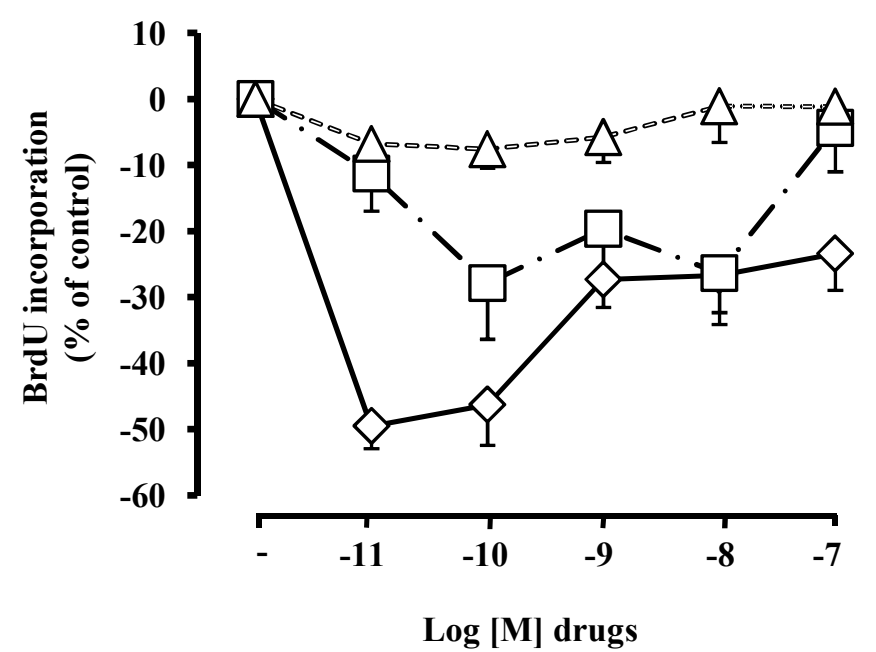
B) $\precsim$ BIM-23120 $\rightleftharpoons$ BIM-23206
$-\Delta$ BIM-23120 + BIM-23206
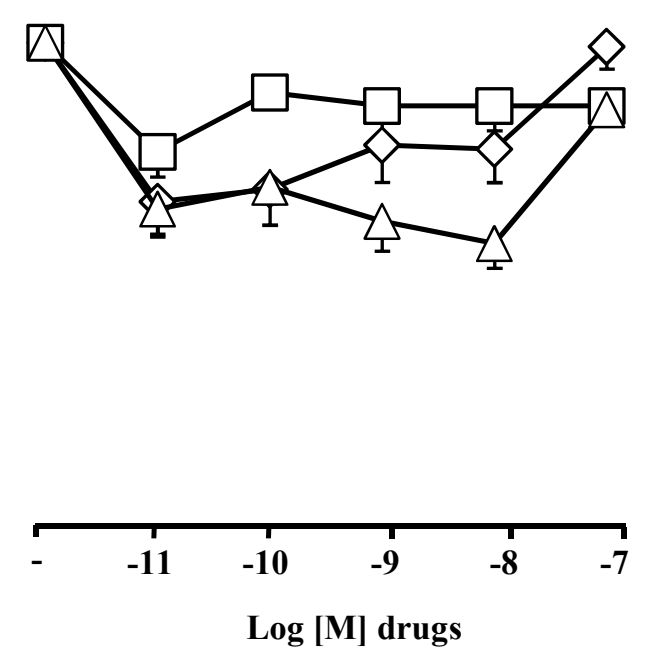

E) $\prec$ BIM-23704 - - BIM-23704 + Ant
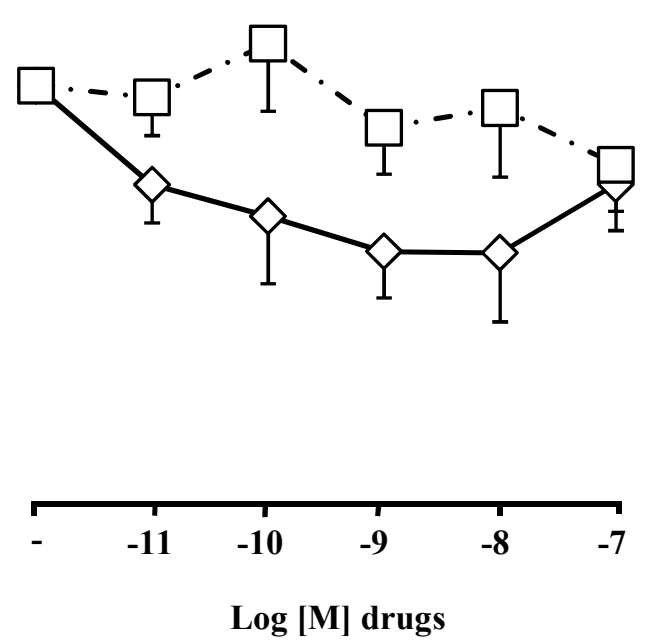

C) $-\Delta$ BIM-23926 $\leftarrow$ BIM-23704
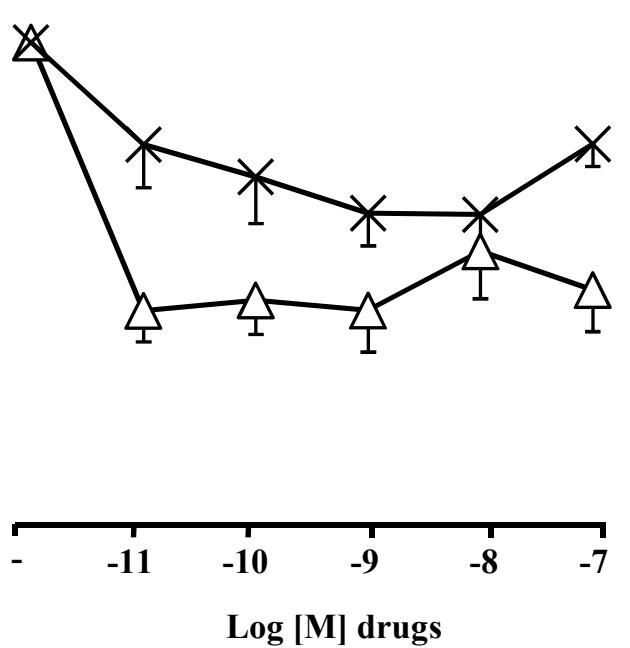
Fig 4

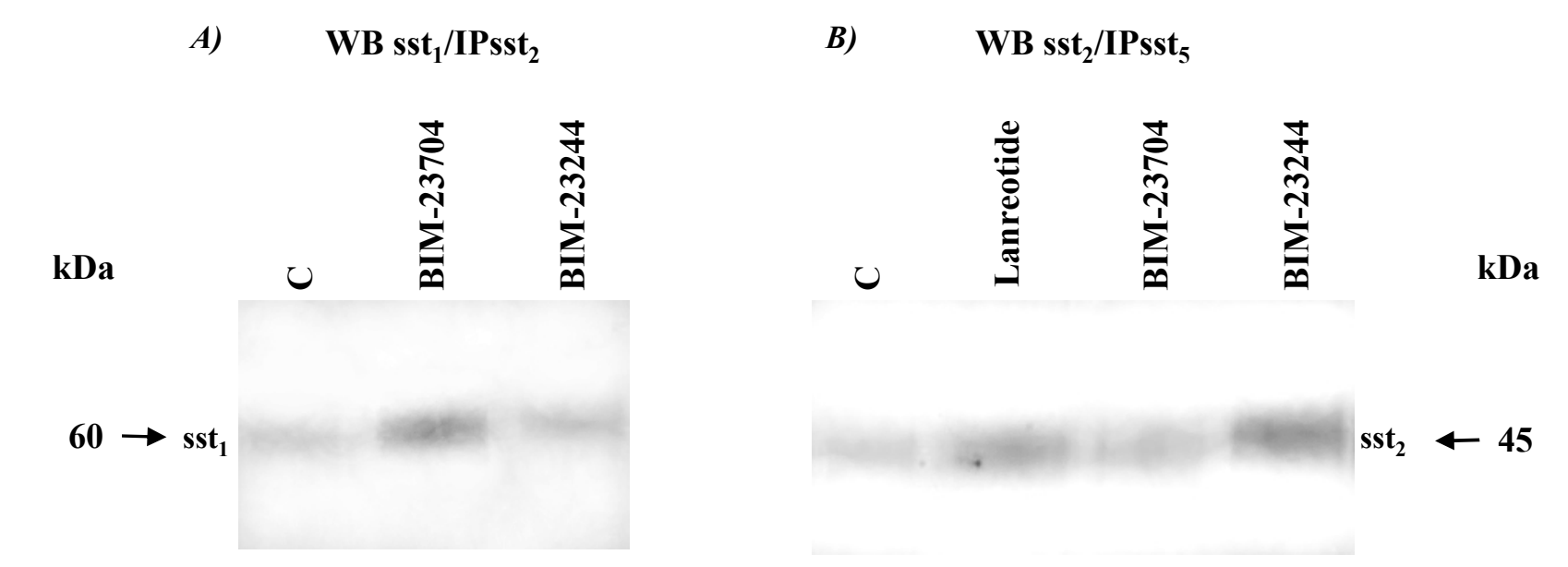

B) WB sst ${ }_{2} /$ IPsst $_{5}$

C)

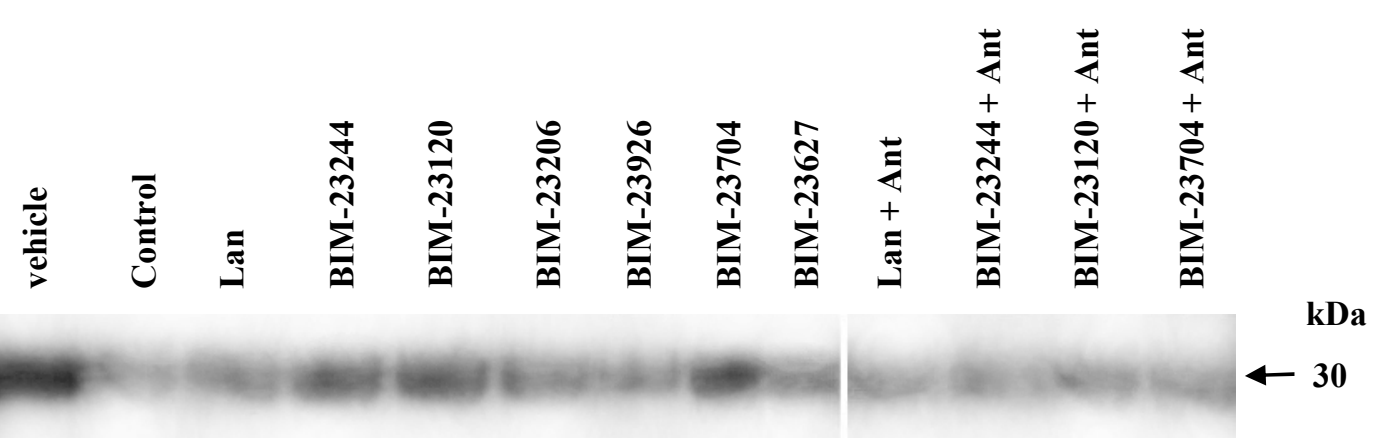




\section{Figure 5}

Fig. 5
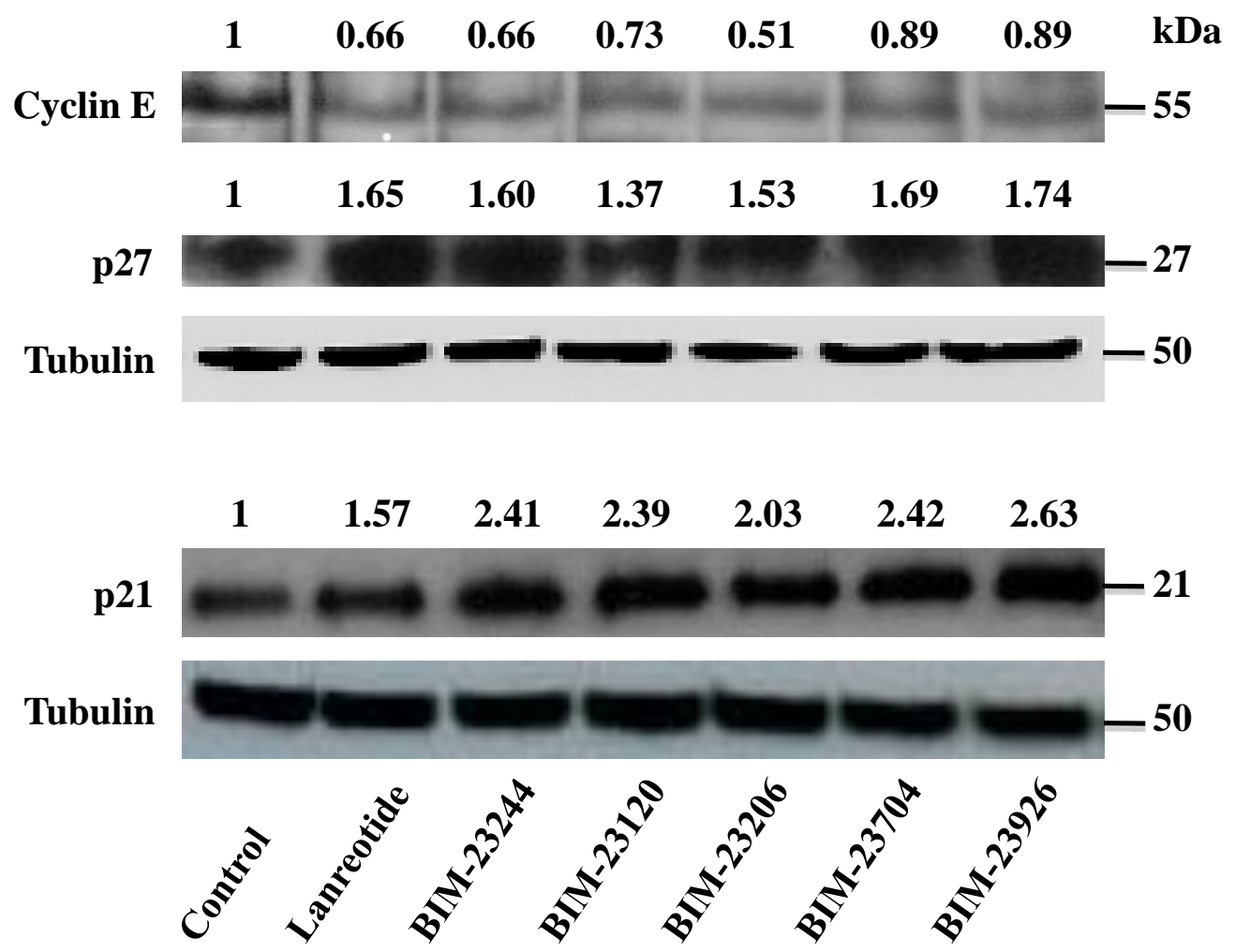